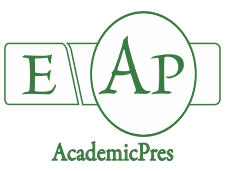

Quintero-Calderón EH et al. (2021)

Notulae Botanicae Horti Agrobotanici Cluj-Napoca

Volume 49, Issue 1, Article number 12120

DOI: $10.15835 /$ nbha 49112120

Research Article

\title{
Rice seedlings showed a higher heat tolerance through the foliar application of biostimulants
}

\author{
Edinson H. QUINTERO-CALDERÓN ${ }^{1}$, \\ Alefsi D. SÁNCHEZ-REINOSO ${ }^{1}$, Cristhian C. CHÁVEZ-ARIAS ${ }^{1}$, \\ Gabriel GARCES-VARON ${ }^{2}$, Hermann RESTREPO-DÍAZ ${ }^{1 *}$
}

${ }^{1}$ Universidad Nacional de Colombia, Sede Bogotá, Facultad de Ciencias Agrarias, Departamento de Agronomía, Carrera 30 No.45-
03, Bogotá, 111321,Colombia; ehquinteroc@unal.edu.co; adsanchezre@unal.edu.co; ccchaveza@unal.edu.co;
hrestrepod@unal.edu.co (*correspondingauthor)
2Federación Nacional de Arroceros, Seccional Saldaña, Carrera18 No.23-112, Saldaña,733570,Colombia;
gabrielgarces@fedearroz.com.co

\section{Abstract}

The use of biostimulants is an agronomic tool to improve plant tolerance to abiotic stress in plants. This study explored the effect of foliar biostimulants sprays such as brassinosteroids (BR), amino acids (AA), nitrophenolates (NP) or a biostimulant based on botanical extracts (BE) on leaf gas exchange parameters [photosynthesis $\left(\mathrm{P}_{N}\right)$, stomatal conductance $\left(\mathrm{g}_{s}\right)$ and transpiration $(E)$ ], leaf photosynthetic pigments, lipid peroxidation of membranes and proline content of two commercial rice genotypes ['Fedearroz 67' and 'Fedearroz 60'] under heat stress conditions. The established treatments were: i) plants without heat stress and foliar applications of biostimulants (C), ii) plants under heat stress and without foliar applications of biostimulants (HT), and iii) plants with heat stress and three foliar applications with $\mathrm{BR}\left(1 \mathrm{~mL} \cdot \mathrm{L}^{-1}\right), \mathrm{AA}(30$ $\left.\mathrm{mL} \cdot \mathrm{L}^{-1}\right)$, NP $\left(15 \mathrm{~mL} \cdot \mathrm{L}^{-1}\right)$ or BE $\left(15 \mathrm{~mL} \cdot \mathrm{L}^{-1}\right)$. The results showed that the application of $\mathrm{BR}, \mathrm{AA}, \mathrm{NP}$ or BE increased the values of $\mathrm{P}_{N}\left(\sim 14.5 \mu \mathrm{mol} \mathrm{CO}{ }_{2} \cdot \mathrm{m}^{-2} \cdot \mathrm{s}^{-1}\right), \mathrm{g}_{s}\left(\sim 0.46 \mathrm{mmol} \cdot \mathrm{m}^{-2} \cdot \mathrm{s}^{-1}\right)$ and $E\left(\sim 43.9 \mathrm{H}_{2} 0\right.$ day $\left.^{-1} \cdot \mathrm{plant}^{-1}\right)$ compared to plants (both genotypes) not treated with biostimulants under heat stress $\left(9.9 \mu \mathrm{mol} \mathrm{CO} \mathrm{CO}_{2} \cdot \mathrm{m}^{-2} \cdot \mathrm{s}^{-1}\right.$ for $\mathrm{P}_{N}, 0.31 \mathrm{mmol} \cdot \mathrm{m}^{-2} \cdot \mathrm{s}^{-1}$ for $\mathrm{g}$, and $27.3 \mathrm{H}_{2} 0 \mathrm{day}^{-1}$. plant $\mathrm{t}^{-1}$ for $E$ ). Foliar biostimulant sprays also caused a lower malondialdehyde and proline production in rice genotypes under heat stress. In conclusion, the biostimulants $\mathrm{BR}, \mathrm{AA}, \mathrm{NP}$, or BE can be considered an agronomic strategy to help mitigate the adverse effects of heat stress in rice areas where periods of high temperatures are expected during the day in Colombia.

Keywords: amino acids; botanical extracts; brassinosteroids; high daytime temperature; leaf gas exchange; lipid peroxidation; nitrophenolates

Abbreviations: AA: amino acids; BE: botanical extracts; BR: brassinosteroids; C: plants without heat stress and foliar biostimulant; $\mathrm{Cx}+\mathrm{c}$ : carotenoids; $E$ : plant transpiration; g: stomatal conductance; HSP: heat shock proteins; HT: plants under heat stress and without foliar biostimulant; HTC: heat tolerance coefficient; MDA: malondialdehyde; NP: nitrophenolates; PCA: principal component analysis; $\mathrm{P}_{N}$ : photosynthesis; $\mathrm{P}_{N} / \mathrm{C}_{i}$ : carboxylation efficiency; ROS: reactive oxygen species; TChl: total chlorophyll; $\mathrm{WUE}_{i}$ intrinsic water use

Received: 16 Oct 2020. Received in revised form: 15 Mar 2021. Accepted: 16 Mar 2021. Published online: O0 Dec 2021.

From Volume 49, Issue 1, 2021, Notulae Botanicae Horti Agrobotanici Cluj-Napoca journal will use article numbers in place of the traditional method of continuous pagination through the volume. The journal will continue to appear quarterly, as before, with four annual numbers. 


\section{Introduction}

Rice (Oryza sativa L.) is one of the most important cereal crops globally, especially in developing countries (Wang et al., 2015). It is considered a staple food because it is an essential source of calories that feeds almost half of the world's population (Hirabayashi et al., 2014; Bahuguna et al., 2017). In Colombia, rice crops occupied 561,073 ha with a production of 2,564,250 $\mathrm{t}$ and an average yield of $4.9 \mathrm{t} \mathrm{ha} \mathrm{a}^{-1}$ in 2019 (Fedearroz, 2020).

Global climate change has generated an increase in the earth's surface temperature in recent decades, and the global mean air temperature is forecast to increase by approximately 2 to $3^{\circ} \mathrm{C}$ by 2050 (IPCC, 2014; Wang et al., 2019). Additionally, heat waves or extreme temperature events are expected to be more intense, frequent, and prolonged than what has been observed in recent years (Hatfield and Prueger, 2015). High daytime temperature events would impact crop productivity (Hatfield and Prueger, 2015; Fan et al., 2018). In Colombia, $65 \%$ of the rice-growing areas are expected to increase temperatures between 2 and $2.5^{\circ} \mathrm{C}$ by 2050 (Ramirez-Villegas et al., 2012).

High daytime temperatures (heat stress) are among the main environmental factors that cause serious adverse effects on rice production (Nigam et al., 2015; Wang et al., 2019). The optimal average temperature for rice growth varies from 25 to $30^{\circ} \mathrm{C}$ during the day and from 20 to $22^{\circ} \mathrm{C}$ for nighttime highs (Chen et al., 2017a; Kilasi et al., 2018). When the temperature exceeds these ranges, it can cause physiological, biochemical and molecular changes in plants such as an increase in reactive oxygen species (ROS) and lipid peroxidation of membranes (Zafar et al., 2018), alteration in leaf gas exchange parameters (photosynthesis, stomatal conductance, and transpiration) and plant water relations (Sahu, 2013; Vivitha et al., 2018).

Photosynthesis $\left(\mathrm{P}_{N}\right)$ is one of the most susceptible physiological processes to heat stress in rice plants, showing a decrease in its values with an increase in daytime temperatures above the optimal levels (28 and 22 ${ }^{\circ} \mathrm{C}$ for day and night, respectively) (Radhakrishna et al., 2018). Sonjaroon et al. (2018) observed a reduction of $57 \%$ in $\mathrm{P}_{N}$ in rice plants subjected to a moderate period (7 days) of high temperature during the day $\left(40^{\circ} \mathrm{C}\right)$. Biochemical markers such as the concentration of leaf photosynthetic pigments (chlorophyll and carotenoids), lipid peroxidation of membranes (malondialdehyde (MDA) production) and accumulation of compatible solutes (proline) have been used to characterize the response of rice plants to stress conditions caused by high daytime temperatures (Sánchez-Reinoso et al., 2014; Thussagunpanit et al., 2015a). According to Hussain et al. (2019), an increase in MDA content and a decrease in chlorophyll concentration indicate a negative impact on the integrity of the cell membrane and the photosynthetic efficiency of plants under heat stress conditions. On the other hand, the accumulation of low-molecular-weight compatible solutes such as proline is considered a primary strategy for protecting and acclimatizing plants to heat stress conditions (Harsh et al., 2016; Shin et al., 2016).

The development of new management practices to induce tolerance to abiotic stress in plants, including heat stress, is acquiring great importance (Baninasab and Ghobadi, 2011; Nguyen et al., 2018). In this regard, the application of biostimulants under unfavorable environmental conditions can induce tolerance to abiotic stress in different crops (Povero et al., 2016; Bulgari et al., 2019). According to du Jardin (2015), a plant biostimulant is "any substance or microorganism applied to plants with the aim to enhance nutrition efficiency, abiotic stress tolerance and/or crop quality traits, regardless of its nutrients content". Biostimulants can be classified as of natural origins such as free amino acids, algae, and botanical extracts, effective microorganisms, humic substances, and chitosan; or synthetic, in which plant growth regulators, phenolic compounds, inorganic salts, and essential elements can be found (Przybysz et al., 2014; du Jardin, 2015). Biostimulants' positive effects on plants include growth promotion, modulation of development and quality traits, nitrate assimilation, hormonal activity, and higher tolerance to environmental stress (du Jardin, 2015; Francesca et al., 2020). Some of the biostimulants studied against different types of abiotic stress have been brassinosteroids (Thussagunpanit 
et al., 2015b), amino acids (Li et al., 2016), nitrophenolates (Przybysz et al., 2014) and botanical extracts (Farooq et al., 2017).

Brassinosteroids (BR) are polyhydroxylated steroidal plant hormones; they are involved in plant growth regulation through their participation in metabolic processes such as photosynthesis, antioxidant activity, osmolyte accumulation, nitrogen metabolism and plant water relations under stress conditions (Ahanger et al., 2018; Anwar et al., 2018). Exogenous applications of BR have been reported to help mitigate the adverse effects of high daytime temperatures in rice (Thussagunpanit et al., 2015a and b), maize (Yadava et al., 2016) and tomato (Zhou et al., 2014) by modulating the components of the antioxidant defense system and inducing heat shock proteins (HSP).

Nitrophenolates (NP) are phenolic compounds that participate in various plant metabolic processes. For example, they increase the concentration of endogenous auxins, promote growth and development, stimulate the absorption of nutrients and improve the photosynthetic and antioxidant activity (Djanaguiraman et al., 2010; Valero et al., 2014). NP can generate a faster and more effective activation of plant defense mechanisms (as they increase the antioxidant system enzymes' capacity and activity) under stress conditions (Przybysz et al., 2014; Kazda et al., 2015). Gulluoglu et al. (2006) reported that the foliar application of NP decreased the negative effects of heat stress in soybean (Glycine max L.) plants by favouring growth (dry mass accumulation) and yield parameters (yield, number of pods and grain weight).

Commercial products of amino acids (AA) can be constituted by active ingredients such as arginine, proline, tryptophan, glycine, or cysteine. AA can increase tolerance to different types of abiotic stress by activating physiological processes such as scavenging of ROS, osmoprotection, increased nutrient availability, and chelation of metals in the soil (Lucini et al., 2015; Van Oosten et al., 2017). The foliar AA sprays generated a better photosynthetic efficiency $\left(\mathrm{F}_{\mathrm{v}} / \mathrm{F}_{\mathrm{m}}\right)$ and higher levels of chlorophyll and carotenoids in Lolium perenne L. plants under heat stress (Botta, 2013). Finally, botanical extracts (BE) have also been considered as a useful alternative for the mitigation of abiotic stress in recent years. They can help to improve various physiological processes that stimulate plant growth and development under abiotic stress conditions (Bulgari et al., 2015; Van Oosten et al., 2017). Zhang et al. (2010) also observed the positive effect of foliar applications of seaweed (Ascophyllum nodosum Jol.) BE on the chlorophyll content and activity of the enzyme nitrate reductase (NR) of Agrostis stolonifera L. plants under high-temperature conditions.

Increases in the intensity and frequencies of high daytime temperature events in Colombia are estimated for the next few years (Ramirez-Villegas et al., 2012). Agronomic management strategies to mitigate the negative effect of heat stress conditions have focused mainly on the evaluation and development of rice genotypes under stress scenarios. These genotypes have been studied to identify physiological response mechanisms that allow strengthening plant breeding programs in Colombia (Restrepo-Díaz and Garces-Varon, 2013; Sánchez-Reinoso et al., 2014). Additionally, crop sowing times have been identified to avoid unfavorable climatic conditions in susceptible phenological stages of the crop (Garcés-Varon and Restrepo-Díaz, 2015; Garces-Varón and Puente, 2019). On the other hand, it has been widely reported that foliar applications of biostimulants decrease the negative impact of different types of abiotic stress in cereals (Przybysz et al., 2014; Thussagunpanit et al., 2015b; Li et al., 2016; Farooq et al., 2017). However, scientific studies on agronomic strategies to mitigate the adverse effect of specific periods of heat stress such as foliar applications of biostimulants (BR, AA, NP, or BE) from a physiological and biochemical point of view remain scarce in the country. This study hypothesizes that foliar applications of four biostimulants can help mitigate the negative effects caused by high daytime temperatures in two rice genotypes (susceptible ('Fedearroz 60') and moderately tolerant ('Fedearroz 67')). For this reason, the objective of this research was to evaluate the effect of foliar applications of four biostimulants (brassinosteroids (BR), amino acids (AA), nitrophenolates (NP) or botanical extracts $(\mathrm{BE})$ ) on leaf gas exchange parameters (photosynthesis, stomatal conductance, and transpiration), photosynthetic pigment content, and biochemical responses (MDA production and proline content) of two commercial rice genotypes subjected to a prolonged period of heat stress. 


\section{Materials and Methods}

\section{General growth conditions and biological material}

An experiment was carried out from December 2015 to March 2016 under glass greenhouse and laboratory conditions at the Faculty of Agricultural Sciences of the Universidad Nacional de Colombia, Bogotá campus ( $4^{\circ} 35^{\prime} 56^{\prime \prime} \mathrm{N}, 74^{\circ} 04^{\prime} 51^{\prime \prime} \mathrm{W}$ ). Initially, seeds of cultivars 'Fedearroz 60' ('F60') (genotype susceptible to high daytime temperatures (Sánchez-Reinoso et al., 2014)) and 'Fedearroz 67' ('F67') (genotype widely cultivated by farmers in Colombia for the last five years) were sown in $1 \mathrm{~L}$ plastic pots containing loam soil in the glass greenhouse. The environmental conditions of the greenhouse during the experiment were: $28 / 20^{\circ} \mathrm{C}$ day/night temperature, $60-80 \%$ relative humidity and a natural photoperiod of $12 \mathrm{~h}\left(1500 \mu \mathrm{mol} \cdot \mathrm{m}^{-2} \cdot \mathrm{s}^{-1}\right.$ of photosynthetically active radiation (PAR) at noon). After seed germination (7 days after sowing (DAS)), the seedlings of both cultivars were watered daily with $50 \mathrm{~mL}$ of a nutrient solution prepared from a complete liquid fertilizer (Nutriponic, Walco SA, Colombia) at a dose of $2.5 \mathrm{~mL} \cdot \mathrm{L}^{-1} \mathrm{H}_{2} \mathrm{O}$ until the end of the experiment (80 DAS). The concentration of the nutrient solution was as follows: $2.08 \mathrm{mM} \mathrm{Ca}\left(\mathrm{NO}_{3}\right)_{2} \cdot 4 \mathrm{H}_{2} \mathrm{O}, 1.99 \mathrm{mM}$ $\mathrm{MgSO}_{4} \cdot 7 \mathrm{H}_{2} \mathrm{O}, 2.00 \mathrm{mM} \mathrm{NH}_{4} \mathrm{H}_{2} \mathrm{PO}_{4}, 10.09 \mathrm{mM} \mathrm{KNO}_{3}, 46.26 \mathrm{nM} \mathrm{H}_{3} \mathrm{BO}_{3}, 0.45 \mathrm{nM} \mathrm{Na}_{2} \mathrm{MoO}_{4} \cdot 2 \mathrm{H}_{2} \mathrm{O}, 0.32$ $\mathrm{nM} \mathrm{CuSO} \mathrm{H}_{4} \cdot 5 \mathrm{H}_{2} \mathrm{O}, 9.19 \mathrm{nM} \mathrm{MnCl}_{2} \cdot 4 \mathrm{H}_{2} \mathrm{O}, 0.76 \mathrm{nM} \mathrm{ZnSO}_{4} \cdot 7 \mathrm{H}_{2} \mathrm{O}$, and $19.75 \mathrm{nM} \mathrm{FeSO} \cdot \mathrm{H}_{2} \mathrm{O}$. In general, the plants were always kept at field capacity to avoid water deficit conditions during the experiment.

\section{Heat stress treatments and foliar applications of biostimulants}

At 57 DAS, when rice plants showed collar formation on the fifth leaf of the main stem (stage V5) (Counce and Keisling, 2000), they were transferred to growth chambers (MLR-351H, Sanyo, Bensenville, Illinois, USA) to determine the different treatments of daytime temperatures. Rice plants were initially divided into two groups to establish heat stress treatments caused by high daytime temperatures. The first group of plants was established with the initial environmental conditions $\left(28 / 20^{\circ} \mathrm{C}\right.$ day/night) (control without heat stress (C)). The second group was exposed to a temperature of $40^{\circ} \mathrm{C}$ between 11:00 and 16:00 for 15 days. The exposure period and the high daytime temperature were selected based on preliminary studies (Restrepo-Diaz and Garces-Varon, 2013; Sánchez-Reinoso et al., 2014). Finally, a $12 \mathrm{~h}$ photoperiod and relative humidity of $60-70 \%$ were established in the chambers during the period of heat stress.

The group of plants subjected to conditions of heat stress $\left(40^{\circ} \mathrm{C}\right)$ was also subdivided into other five groups to establish foliar treatments with biostimulants, which were as follows: brassinosteroids (BR) at a dose of $1 \mathrm{~mL} \cdot \mathrm{L}^{-1}$, amino acids (AA) at a dose of $30 \mathrm{~mL} \cdot \mathrm{L}^{-1}$ (Globafol, Valagro SpA, Atessa, Italy), nitrophenolates (NP) at a dose of $15 \mathrm{~mL} \cdot \mathrm{L}^{-1}$ (Atonik, Arysta Lifescience SA, Bogotá, Colombia), a commercial product based on botanical extracts, gibberellins, auxins and cytokinins (BE) at a dose of $15 \mathrm{~mL} \cdot \mathrm{L}^{-1}$ (Biozyme TF, Arysta Lifescience SA, Bogotá, Colombia) and plants without application of biostimulants (HT). Rice plants of treatments $\mathrm{C}$ and HT were only sprayed with distilled water. At the end of the experiment (80 DAS), a total of eight treatment groups were obtained depending on the heat stress condition and foliar application of biostimulants, which are summarized as follows: i) plants without stress due to high daytime temperatures (40 ${ }^{\circ} \mathrm{C}$ ) and without foliar applications of biostimulants (control without heat stress and foliar application (C)); ii) plants subjected to heat stress and without foliar applications of biostimulants (heat stress without foliar application (HT)); iii) plants with heat stress and with three foliar applications of BR, AA, NP or BE. The concentrations of all biostimulants (BR, AA, NP, or $\mathrm{BE}$ ) were selected from the doses of the commercial products recommended in rice-producing areas of Colombia. Finally, Table 1 summarizes the characteristics of the biostimulants used in this study.

Biostimulants' applications were carried out at three different times during the experiment: i) foliar application 54 DAS, ii) foliar application 65 DAS, and iii) foliar application 75 DAS. In general, each biostimulant application was carried out between 07:00 and 09:00, using a Style 1.5 compression sprayer (Matabi, Spain) with an application volume of $15 \mathrm{~mL} \mathrm{H}_{2} \mathrm{O}$ per plant, wetting the upper and lower surfaces of leaves. All foliar applications carried a surfactant adjuvant (INEX-A, Cosmoagro, Colombia) at a dose of $0.1 \%$ 
$(\mathrm{v} / \mathrm{v})$. The treatments were arranged in a completely randomized design with five replicates, and each replicate consisted of two plants. Finally, the experiment lasted 80 days.

Table 1. The chemical name of the active ingredient, trade name, manufacturer, and biological activity of the biostimulants applied in rice plants (Oryza sativa L.) of the genotypes 'Fedearroz 67' and 'Fedearroz 60 ' under heat stress conditions

\begin{tabular}{|c|c|c|}
\hline Chemical name of the active ingredient & Trade name (Manufacturer) & Biological activity \\
\hline $\begin{array}{c}(25 R)-3 \beta .5 \alpha-\text { dihydroxy-spirostan-6- } \\
\text { one }\end{array}$ & $\begin{array}{l}\text { Biomex DI-31 (Minerales } \\
\text { exclusivos SA, Bogotá, Colombia) }\end{array}$ & $\begin{array}{c}\text { Regulates plant development by } \\
\text { modulating various signaling } \\
\text { pathways }\end{array}$ \\
\hline $\begin{array}{l}\text { Plant-based amino acids (arginine, } \\
\text { proline, tryptophan, glycine, cysteine), } \\
\text { nitrogen and soluble potassium }\end{array}$ & $\begin{array}{l}\text { Globafol (Valagro SpA, } \\
\text { Atessa, Italy Italy) }\end{array}$ & $\begin{array}{l}\text { Regulates the synthesis of } \\
\text { proteins and enhances the } \\
\text { photosynthetic activity of plants }\end{array}$ \\
\hline $\begin{array}{c}\text { Sodium p- nitrophenolate, Sodium o- } \\
\text { nitrophenolate, Sodium } 5 \\
\text { nitroguaiacolate }\end{array}$ & $\begin{array}{c}\text { Atonik }^{\circ} \text { (Arysta Lifescience SA, } \\
\text { Bogotá, Colombia) }\end{array}$ & $\begin{array}{c}\text { Induces the activity of naturally } \\
\text { synthesized auxins and the } \\
\text { enzyme nitrate reductase }\end{array}$ \\
\hline $\begin{array}{l}\text { Plant-based extracts, gibberellins, } \\
\text { indoleacetic acid and zeatin }\end{array}$ & $\begin{array}{c}\text { Biozyme }^{\oplus} \mathrm{TF} \text { (Arysta Lifescience } \\
\text { SA, Bogotá, Colombia) }\end{array}$ & $\begin{array}{l}\text { Regulates cell division in } \\
\text { meristems, as well as cell } \\
\text { elongation }\end{array}$ \\
\hline
\end{tabular}

\section{Leaf gas exchange and water use efficiency}

One mature leaf per plant was selected to carry out gas exchange readings. The leaves were previously adapted to the surrounding environment, and the leaf surface was not touched to avoid stomatal closure before measurements. Photosynthesis $\left(\mathrm{P}_{N}\right)$, stomatal conductance $\left(\mathrm{g}_{s}\right)$, and intercellular $\mathrm{CO}_{2}$ concentrations inside the leaf $\left(\mathrm{C}_{i}\right)$ were estimated using a portable photosynthesis meter (LI-COR 6200, Lincoln, NE, USA) between 10:00 and 15:00 h. During the readings, the conditions of the LiCor chamber were as follows: photosynthetically active radiation of $700 \mu \mathrm{mol} \cdot \mathrm{m}^{-2} \cdot \mathrm{s}^{-1}$, leaf temperature $27 \pm 5^{\circ} \mathrm{C}$, and leaf-air vapor pressure difference $1.8 \pm 0.5 \mathrm{kPa}$. With the values of $\mathrm{P}_{N}, \mathrm{~g}_{,} \mathrm{C}_{i}$ and ambient $\mathrm{CO}_{2}$ concentration $\left(\mathrm{C}_{a}\right)$ we calculated, respectively, the stomatal limitation $\left(1-\mathrm{C}_{i} / \mathrm{C}_{a}=\mathrm{L}_{S}\right.$ ) (Yin et al., 2006), the intrinsic water use efficiency given by the ratio $\left(\mathrm{P}_{N} / \mathrm{g}_{s}=\mathrm{WUE}{ }_{i}\right)$ and the carboxylation efficiency $\left(\mathrm{P}_{N} / \mathrm{C}_{i}\right)$ (Flexas et al., 2001). Two measurements were carried out per plant. Finally, the total plant transpiration $(E)$ was obtained using the gravimetric technique described by Sánchez-Reinoso et al. (2014), which consisted of covering pots with plastic to avoid water loss due to evaporation and weighing pots daily before and after irrigation between 57 and 80 DAS. The transpiration rate was expressed in $\mathrm{mg} \mathrm{H}_{2} \mathrm{O} \cdot \mathrm{g}^{-1} \mathrm{FW} \cdot \mathrm{h}^{-1}$.

\section{Leaf photosynthetic pigments}

The equations described by Wellburn (1994) were used to estimate chlorophyll total (TChl) and carotenoid $(\mathrm{Cx}+\mathrm{c})$ content from $50 \mathrm{mg}$ of the tissue sample from the same leaves used to measure the gas exchange variables. The tissue samples were homogenized in $3 \mathrm{~mL}$ of $80 \%$ acetone and then centrifuged (Model 420101, Becton Dickinson Primary Care Diagnostics, MD, USA) at $5000 \mathrm{rpm}$ for 10 minutes to remove particles. The supernatant was diluted to a final volume of $6 \mathrm{ml}$ by adding $80 \%$ acetone (Sims and Gamon, 2002). Chlorophyll content was determined at 663 , and $646 \mathrm{~nm}$ and carotenoids were determined at $470 \mathrm{~nm}$ using a spectrophotometer (Spectronic BioMate 3 UV-vis Thermo, Madison, WI). Leaf photosynthetic pigments were determined at 80 DAS.

\section{Proline and malondialdehyde content}

The same leaves collected for the determination of leaf photosynthetic pigments were used for the proline and MDA content in all treatments. The method described by Bates et al. (1973) was used to estimate 
the proline content in each of the evaluated treatments. Leaves were collected from the upper third of the plant; samples of $300 \mathrm{mg}$ of this plant material were homogenized in liquid nitrogen and stored for further analysis. Subsequently, $10 \mathrm{~mL}$ of a $3 \%$ aqueous solution of sulfosalicylic acid was added to the samples and Whatman paper (No. 2) was used to filter them. Then, $2 \mathrm{~mL}$ of the filtrate was reacted with $2 \mathrm{~mL}$ of ninhydrin acid and $2 \mathrm{~mL}$ of glacial acetic acid. The mixture was placed in a water bath at $90^{\circ} \mathrm{C}$ for $1 \mathrm{~h}$ and incubation on ice was used to stop the reaction. The resulting solution was dissolved in $4 \mathrm{~mL}$ of toluene and vortexed (V-1, BOECO, Germany) for $30 \mathrm{~s}$. Finally, the absorbance readings were determined at $520 \mathrm{~nm}$ with the same spectrophotometer used in the quantification of leaf photosynthetic pigments (Spectronic BioMate 3 UV-Vis, Thermo, Madison, WI, USA). The proline content was calculated with the fresh weight of the sample using a standard calibration curve (equation 1).

$\frac{\mu \mathrm{mol} \text { Proline }}{\text { fresh vegetal material }}=\frac{\left[\frac{\left(\frac{\mu \mathrm{g} \text { Proline }}{\mathrm{mL}} \times \mathrm{mL} \text { Toluene }\right)}{\frac{115.5 \mu \mathrm{g}}{\mu \mathrm{mol}}}\right]}{\left[\frac{\mathrm{g} \mathrm{sample}}{5}\right]}$

The thiobarbituric acid (TBA) method described by Hodges et al. (1999) was used to estimate membrane lipid peroxidation (malondialdehyde (MDA)). Samples of $300 \mathrm{mg}$ of leaves from the upper third of the plants from the different treatments were macerated and stored in liquid nitrogen. The samples were centrifuged (Model 420101, Becton Dickinson Primary Care Diagnostics, MD, USA) at $5000 \mathrm{rpm}$ for $10 \mathrm{~min}$, and absorbances were estimated at 440,532 and $600 \mathrm{~nm}$ with a spectrophotometer. Finally, the extinction coefficient $\left(157 \mathrm{M} \mathrm{mL}^{-1}\right)$ was used to obtain the MDA concentration. Proline and MDA readings were performed at 80 DAS.

\section{Heat tolerance coefficient (HTC)}

The heat tolerance coefficient (HTC) was calculated to estimate rice plants' photosynthetic responses to the impact of high daytime temperatures and foliar applications of biostimulants. HTC was calculated by adjusting the equation described by Liu et al. (2010) (equation 2).

$$
\mathrm{HTC}=\frac{\text { Net photosinthesis of plants subjected to heat stress }}{\text { Net photosinthesis of plants without heat stress (control plants) }}
$$

\section{Statistical analysis}

Data were analysed using a factorial arrangement where the first factor corresponded to the rice genotypes ('F60' and 'F67') and the second factor was the biostimulants used in foliar applications (BR, AA, $\mathrm{NP}$ or BE). Each treatment group consisted of 10 plants. A principal component analysis was carried out using the InfoStat 2016 program (analytical software, Universidad Nacional de Cordoba, Argentina) to select the best biostimulants used under heat stress conditions. In all cases, an analysis of variance (ANOVA) was carried out and when significant differences $(P \leq 0.05)$ were observed, a post hoc Tukey test was used for the comparison of means. Percentage values were transformed using the arcsine function. Data were analysed using the Statistix v 9.0 program (Analytical Software, Tallahassee, FL, USA). Figures were performed using Sigmaplot software (version 12.0; Systat Software, San Jose, CA, USA). 


\section{Results}

Table 2 summarizes the analysis of variance (ANOVA) of the effect of two rice genotypes ('F60' and 'F67') subjected to heat stress conditions and treated with foliar applications of biostimulants (BR, AA, NP or $\mathrm{BE}$ ) on the photosynthetic rate (PN), stomatal conductance (gs), transpiration (E), stomatal limitation (LS), carboxylation efficiency ( $\mathrm{PN} / \mathrm{Ci}$ ), intrinsic water use efficiency (WUEi), leaf photosynthetic pigments (TChl and $\mathrm{Cx}+\mathrm{x})$, malondialdehyde (MDA) and proline content at $80 \mathrm{DAS}$.

Table 2. F-statistical probability $(\mathrm{P}>\mathrm{F})$ of the effects of foliar applications of four biostimulants (B) [brassinosteroids (BR), amino acids (AA), nitrophenolates (NP) or botanical extracts (BE)] on the physiological and biochemical variables of rice plants (Oryza sativa L.) of the genotypes (G) 'Fedearroz 67' and 'Fedearroz 60' under a prolonged period (15 days) of high daytime temperatures $\left(40{ }^{\circ} \mathrm{C}\right)$ at 80 days after sowing (DAS)

\begin{tabular}{|c|c|c|c|c|c|}
\hline \multirow{2}{*}{ Variable } & \multirow{2}{*}{ Abbr. } & \multicolumn{3}{|c|}{ Variation source } & \multirow{2}{*}{$\mathrm{CV}(\%)^{2}$} \\
\hline & & Genotype $(\mathrm{G})$ & Biostimulant (B) & $\mathrm{G} \times \mathrm{B}$ & \\
\hline Photosynthesis & $\mathrm{P}_{N}$ & $\begin{array}{c}F=56.2 ; d f=1 \\
P=0.0003\end{array}$ & $\begin{array}{c}F=112.1 ; d f=5 \\
P=0.0000\end{array}$ & $\begin{array}{c}F=5.7 ; d f=5 ; \\
P=0.0000\end{array}$ & 6.33 \\
\hline Stomatal conductance & $\mathrm{g}_{s}$ & $\begin{array}{c}F=8.8 ; d f=1 ; \\
P=0.0046\end{array}$ & $\begin{array}{c}F=105.1 ; d f=5 \\
P=0.0000\end{array}$ & $\begin{array}{c}F=10.6 ; d f=5 \\
P=0.0000\end{array}$ & 9.23 \\
\hline Plant transpiration & $E$ & $\begin{array}{c}F=1.7 ; d f=1 ; \\
P=0.1955\end{array}$ & $\begin{array}{c}F=27.3 ; d f=5 \\
P=0.0000\end{array}$ & $\begin{array}{c}F=2.7 ; d f=5 \\
P=0.0299\end{array}$ & 14.3 \\
\hline Stomatal limitation & $\mathrm{L}_{s}$ & $\begin{array}{c}F=4.3 ; d f=1 ; \\
P=0.0433\end{array}$ & $\begin{array}{c}F=32.1 ; d f=5 ; \\
P=0.0000\end{array}$ & $\begin{array}{c}F=3.5 ; d f=5 \\
P=0.0080\end{array}$ & 8.89 \\
\hline Carboxylation efficiency & $\mathrm{P}_{N} / \mathrm{C}_{i}$ & $\begin{array}{c}F=14.8 ; d f=1 \\
P=0.0004\end{array}$ & $\begin{array}{c}F=151.0 ; d f=5 ; \\
P=0.0000\end{array}$ & $\begin{array}{c}F=8.9 ; d f=5 \\
P=0.0000\end{array}$ & 9.23 \\
\hline Intrinsic water use efficiency & $\mathrm{WUE}_{i}$ & $\begin{array}{c}F=212.2 ; d f=1 ; \\
P=0.0000\end{array}$ & $\begin{array}{c}F=22.4 ; d f=5 \\
P=0.0000\end{array}$ & $\begin{array}{c}F=3.4 ; d f=5 \\
P=0.0105\end{array}$ & 4.43 \\
\hline Total chlorophyll & TChl & $\begin{array}{c}F=221.4 ; d f=1 \\
P=0.0000\end{array}$ & $\begin{array}{c}F=272.4 ; d f=5 \\
P=0.0000\end{array}$ & $\begin{array}{c}F=0.8 ; d f=5 \\
P=0.5241\end{array}$ & 3.11 \\
\hline Carotenoids & $\mathrm{Cx}+\mathrm{c}$ & $\begin{array}{c}F=238.2 ; d f=1 ; \\
P=0.0000\end{array}$ & $\begin{array}{c}F=167.6 ; d f=5 ; \\
P=0.0000\end{array}$ & $\begin{array}{c}F=0.1 ; d f=5 ; \\
P=0.9866\end{array}$ & 3.00 \\
\hline Proline & & $\begin{array}{c}F=48.8 ; d f=1 ; \\
P=0.0000\end{array}$ & $\begin{array}{c}F=112.6 ; d f=5 \\
P=0.0000\end{array}$ & $\begin{array}{c}F=10.1 ; d f=5 \\
P=0.0000\end{array}$ & 8.39 \\
\hline Malondialdehyde & MDA & $\begin{array}{c}F=305.5 ; d f=1 ; \\
P=0.0000\end{array}$ & $\begin{array}{c}F=212.1 ; d f=5 \\
P=0.0000\end{array}$ & $\begin{array}{c}F=3.6 ; d f=5 \\
P=0.0078\end{array}$ & 4.91 \\
\hline
\end{tabular}

${ }^{\mathrm{z}} \mathrm{CV}=$ Coefficient of variation

Leaf gas exchange parameters and intrinsic water use efficiency ( $W U E_{i}$ )

Differences were observed in the interaction between the rice genotypes used ('F60' and 'F67') and the biostimulants (BR, AA, NP or BE) under a condition of high daytime temperature on $\mathrm{P}_{N}(P=0.0000), \mathrm{g}_{s}$ ( $P=0.0000), E(P=0.0299), \mathrm{L}_{S}(P=0.0080), \mathrm{P}_{N} / \mathrm{C}_{i}(P=0.0000)$, and $\mathrm{WUE}_{i}(P=0.0105)$ at 80 DAS (Table 2$)$. In general, heat stress caused lower values of $\mathrm{P}_{N}, \mathrm{~g}_{s}, E$, and $\mathrm{P}_{N} / \mathrm{C}_{i}$ in rice plants of both genotypes ('F60' and 'F67') without foliar application of biostimulants (heat stress (HT)). However, an opposite trend was observed for $\mathrm{L}_{s}$ and $\mathrm{WUE}_{i}$ in these same plants (higher values) (Figures 1 and 2). A positive response could be seen when heat-stressed 'F67' and 'F60' rice plants were sprayed with biostimulants. In this regard, the foliar application of BR caused higher $\mathrm{P}_{N}$ values $\left(17.2 \mu \mathrm{mol} \mathrm{CO} \cdot \mathrm{m}^{-2} \cdot \mathrm{s}^{-1}\right.$ for ' $\mathrm{F} 67$ ' and $14.6 \mu \mathrm{mol} \mathrm{CO} \cdot \cdot \mathrm{m}^{-2} \cdot \mathrm{s}^{-1}$ for ' $\mathrm{F} 60$ '). Plants with AA sprays showed intermediate readings $\left(15.3 \mu \mathrm{mol} \mathrm{CO} \cdot \mathrm{m}^{-2} \cdot \mathrm{s}^{-1}\right.$ for ' $\mathrm{F} 67$ ' and $14.1 \mu \mathrm{mol} \mathrm{CO} \mathrm{CO}_{2} \cdot \mathrm{m}^{-2} \cdot \mathrm{s}^{-1}$ for ' $\mathrm{F} 60$ '), whereas NP and BE exhibited mean values of $14.8 \mu \mathrm{mol} \mathrm{CO} 2 \cdot \mathrm{m}^{-2} \cdot \mathrm{s}^{-1}$ for ${ }^{~} \mathrm{~F} 67$ ' and $12.4 \mu \mathrm{mol} \mathrm{CO} 2 \cdot \mathrm{m}^{-2} \cdot \mathrm{s}^{-1}$ for 'F60'. Finally, plants only subjected to HT showed values of $11.3 \mu \mathrm{mol} \mathrm{CO}{ }^{\cdot} \cdot \mathrm{m}^{-}{ }^{2} \cdot \mathrm{s}^{-}{ }^{1}$ for ' $\mathrm{F} 67$ ' and $8.4 \mu \mathrm{mol}$ $\mathrm{CO}_{2} \cdot \mathrm{m}^{-2} \cdot \mathrm{s}^{-1}$ for 'F60' (Figure $\left.1 \mathrm{~A}\right)$. 
The variable gswas favoured by foliar sprays of $\mathrm{BR}\left(0.54 \mathrm{mmol} \cdot \mathrm{m}^{-2} \cdot \mathrm{s}^{-1}\right.$ for ' $\mathrm{F} 67$ ' and $0.64 \mathrm{mmol} \cdot \mathrm{m}^{-2} \cdot \mathrm{s}^{-1}$ for 'F 60 ') or AA (mean values $0.45 \mathrm{mmol} \cdot \mathrm{m}^{-2} \cdot \mathrm{s}^{-1}$ ) in both genotypes subjected to heat stress conditions. On the other hand, foliar applications of NPs $\left(0.43 \mathrm{mmol} \cdot \mathrm{m}^{-2} \cdot \mathrm{s}^{-1}\right)$ only favoured $\mathrm{g}_{s}$ in plants of genotype ' $\mathrm{F} 67$ ' under conditions of high diurnal temperatures compared to HT plants of both genotypes (mean values $0.31 \mathrm{mmol} \cdot \mathrm{m}$ $\left.{ }^{2} \cdot \mathrm{s}^{-1}\right)$ (Figure $\left.1 \mathrm{~B}\right)$. An increase in the $E$ values of ' $\mathrm{F} 60$ ' plants subjected to heat stress was mainly observed in the treatment with BR sprays $\left(48.6 \mathrm{H}_{2} 0 \mathrm{day}^{-1}\right.$.plant $\left.{ }^{-1}\right)$ compared to HT plants of the same genotype $\left(30.1 \mathrm{H}_{2} \mathrm{O}\right.$ day ${ }^{1}$.plant $\left.{ }^{-1}\right)$. The transpiration of ' $\mathrm{F} 67$ ' plants under heat stress was also stimulated with the foliar application of $\mathrm{BE}, \mathrm{NP}$, or $\mathrm{BR}$ showing mean values of $47.1 \mathrm{H}_{2} \mathrm{O}$ day $^{-1}$. plant ${ }^{-1}$ compared to $\mathrm{HT}$ plants without biostimulant sprays $\left(24.4 \mathrm{H}_{2} 0\right.$ day $^{-1}$.plant ${ }^{-1}$ ) (Figure $1 \mathrm{C}$ ). On the other hand, the foliar application mainly of $\mathrm{BR}$ (mean values 0.166 ) or $\mathrm{AA}$ (mean values 0.201 ) favoured $\mathrm{L}_{S}$ in plants of both rice genotypes under heat stress compared to HT plants (mean values 0.305 ) (Figure 1D).

Figure 2 shows that $\mathrm{P}_{N} / \mathrm{C}_{i}$ and $\mathrm{WUE}_{i}$ showed opposite trends between them. $\mathrm{P}_{N} / \mathrm{C}_{i}$ was favoured by foliar applications of BR, AA, NP or BE in both genotypes ('F67' and ' $F 60$ '), observing that foliar treatments with these biostimulants helped improve the carboxylation of plants under heat stress (Figure 2A). However, foliar applications mainly of BR caused a decrease in $\mathrm{WUE}_{i}\left(28.9 \mu \mathrm{mol} \cdot \mathrm{mmol}^{-1}\right.$ for ' $\mathrm{F} 60$ ' and $31.7 \mu \mathrm{mol} \cdot \mathrm{mmol}^{-}$ ${ }^{1}$ for 'F67') compared to control plants under heat stress (HT) with values of $35.1 \mu \mathrm{mol} \cdot \mathrm{mmol}^{-1}$ for ' $\mathrm{F} 67$ ' and $30.1 \mu \mathrm{mol} \cdot \mathrm{mmol}^{-1}$ for 'F60' (Figure 2B). Finally, the plants without heat stress and foliar application of biostimulants (C) always showed higher $\mathrm{P}_{N}, \mathrm{~g}_{s} E$ and $\mathrm{P}_{N} / \mathrm{C}_{i}$ and lower $\mathrm{L}_{S}$ and $\mathrm{WUE}_{i}$ in both rice genotypes ('F67' and 'F60') (Figures 1 and 2).

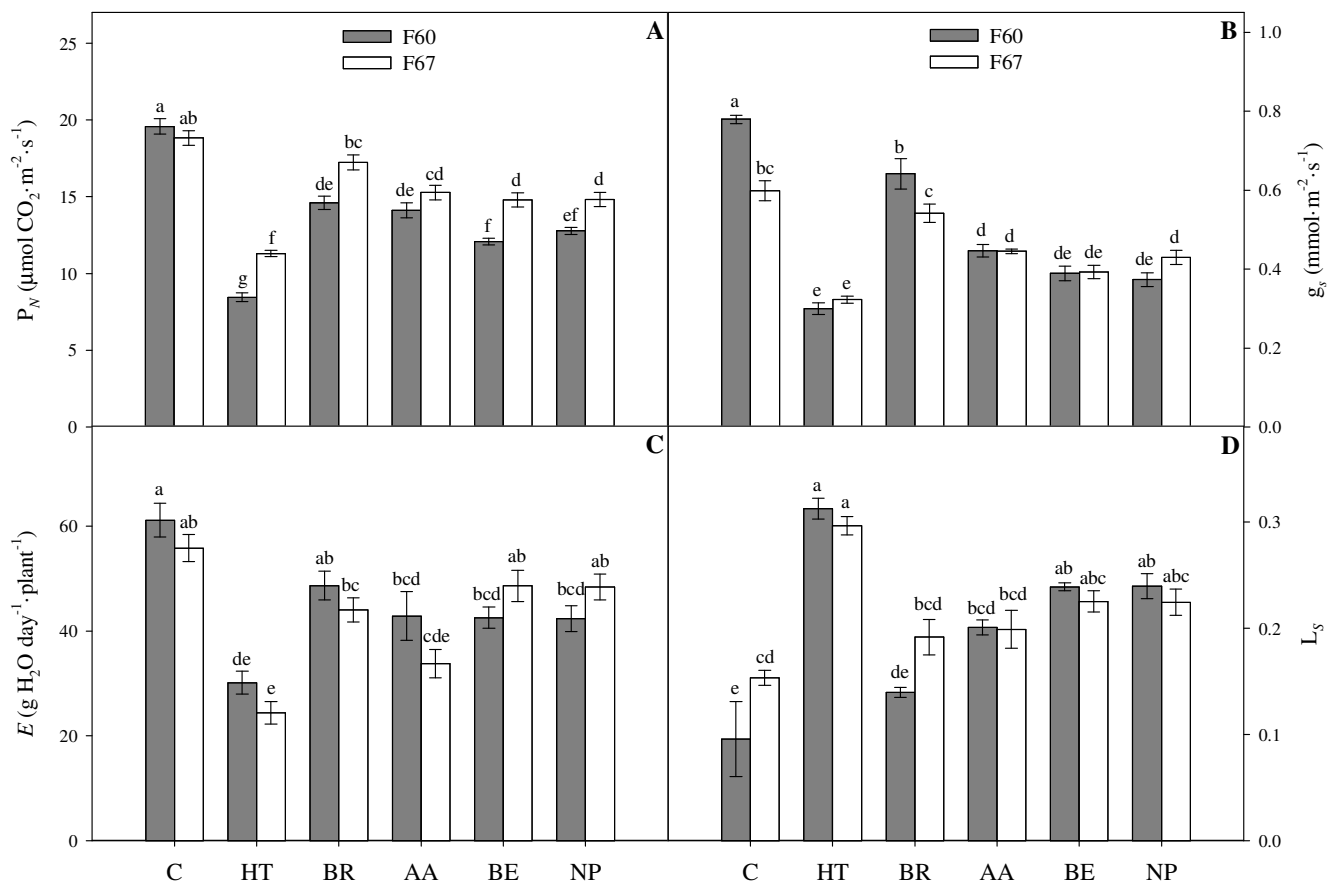

Figure 1. Leaf photosynthesis $\left(\mathrm{P}_{N}\right)(\mathrm{A})$, stomatal conductance $\left(\mathrm{g}_{s}\right)(\mathrm{B})$, plant transpiration $(E)(\mathrm{C})$, and stomatal limitation $\left(\mathrm{L}_{S}\right)(\mathrm{D})$ of rice plants (Oryza sativa L.) of the genotypes 'Fedearroz 67' ('F67') and 'Fedearroz 60 ' ('F60') under heat stress and foliar application of four different biostimulants at 80 days after sowing (DAS)

Each bar represents the mean of 10 plants $(n=10) \pm$ standard error. Bars followed by different letters indicate statistically significant differences according to the Tukey test $(\mathrm{P} \leq 0.05)$

C: control plants without heat stress $\left(28^{\circ} \mathrm{C}\right)$; HT: plants with a prolonged period (15 days) of high daytime temperatures $\left(40^{\circ} \mathrm{C}\right)$; BR: heat-stressed plants sprayed with brassinosteroids; AA: heat-stressed plants sprayed with amino acids; NP: heat-stressed plants sprayed with nitrophenolates; and BE: heat-stressed plants sprayed with botanical extracts 


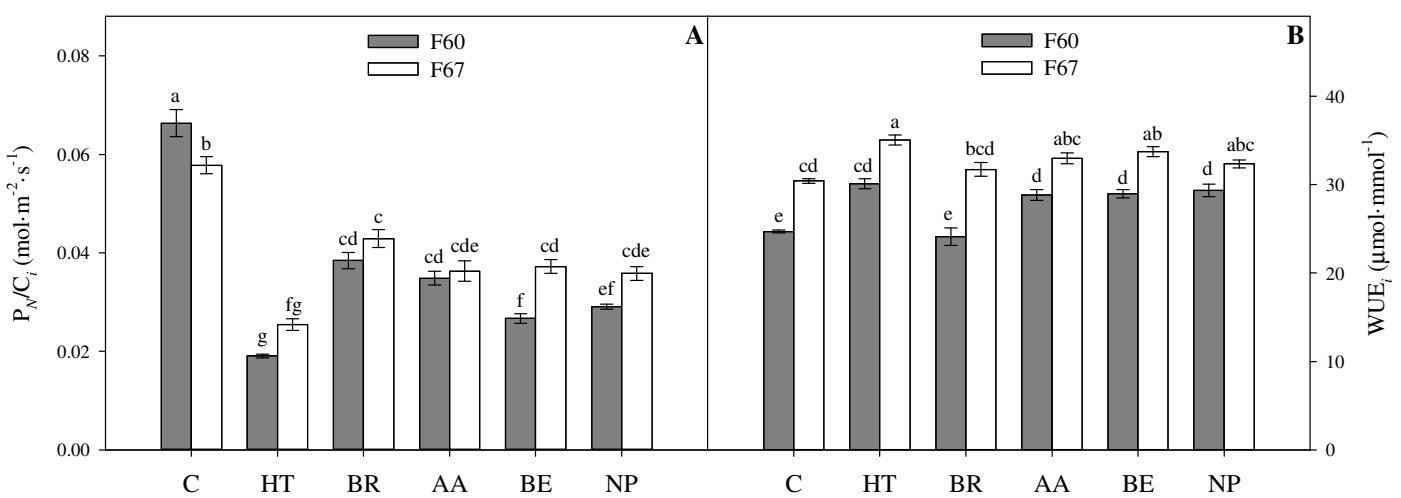

Figure 2. Carboxylation efficiency $\left(\mathrm{P}_{N} / \mathrm{C}_{i}\right)(\mathrm{A})$ and intrinsic water use efficiency (WUE $\left.{ }_{i}\right)(\mathrm{B})$ of rice plants (Oryza sativa L.) of the genotypes 'Fedearroz 67' ('F67') and 'Fedearroz 60' ('F60') under heat stress and foliar application of four different biostimulants at 80 days after sowing (DAS)

Each bar represents the mean of 10 plants $(n=10) \pm$ standard error. Bars followed by different letters indicate statistically significant differences according to the Tukey test $(\mathrm{P} \leq 0.05)$

C: control plants without heat stress $\left(28^{\circ} \mathrm{C}\right)$; HT: plants with a prolonged period ( 15 days) of high daytime temperatures $\left(40^{\circ} \mathrm{C}\right)$; BR: heat-stressed plants sprayed with brassinosteroids; AA: heat-stressed plants sprayed with amino acids; NP: heat-stressed plants sprayed with nitrophenolates; and BE: heat-stressed plants sprayed with botanical extracts

\section{Leaf photosynthetic pigments}

Table 2 shows that differences were only obtained for the factors genotype and biostimulant in the treatments evaluated on the content of total chlorophyll (TChl) $(P=0.000$ and $0=000$, respectively) and carotenoids $(\mathrm{C} x+\mathrm{c})(P=0.000$ and $0=000$, respectively) at the end of the experiment (80 DAS). The content of leaf photosynthetic pigments (TChl and $\mathrm{Cx}+\mathrm{c}$ ) was affected when rice plants were stressed by heat and were not treated with any biostimulant $\left(1.07 \mathrm{mg} \cdot \mathrm{mg}^{-1} \cdot \mathrm{FW}\right.$ for TChl and $0.52 \mathrm{mg} \cdot \mathrm{mg}^{-1} \cdot \mathrm{FW}$ for $\left.\mathrm{Cx}+\mathrm{c}\right)$ compared to plants with foliar sprays of $\mathrm{BR}, \mathrm{AA}, \mathrm{BE}$ or $\mathrm{NP}$, with mean values of $1.41 \mathrm{mg} \cdot \mathrm{mg}^{-1} \cdot \mathrm{FW}$ and $0.58 \mathrm{mg}^{-\mathrm{mg}^{-1}} \cdot \mathrm{FW}$ for TChl and $\mathrm{Cx}+\mathrm{c}$, respectively. Plants without heat stress and biostimulant sprays $(\mathrm{C})$ showed the highest values of TChl $\left(1.78 \mathrm{mg} \cdot \mathrm{mg}^{-1} \cdot \mathrm{FW}\right)$ and $\mathrm{Cx}+\mathrm{c}\left(0.72 \mathrm{mg} \cdot \mathrm{mg}^{-1} \cdot \mathrm{FW}\right)($ Figures $3 \mathrm{~A}$ and $\mathrm{B})$.

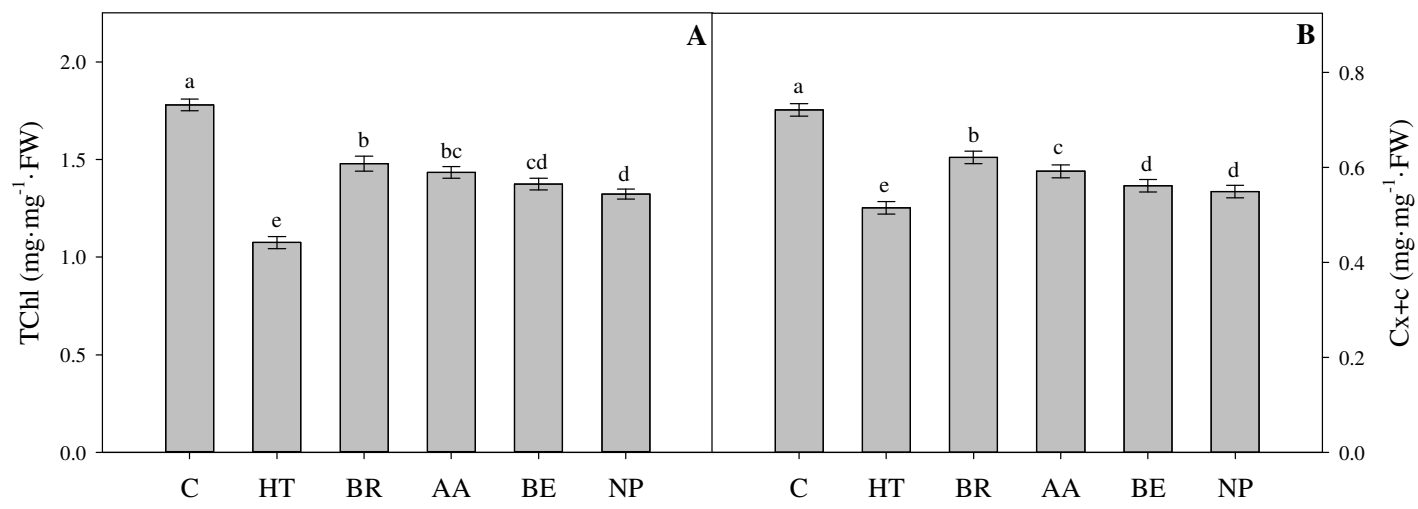

Figure 3. Total chlorophyll content (TChl) (A) and carotenoids $(\mathrm{Cx}+\mathrm{c})(\mathrm{B})$ of rice plants (Oryza sativa L.) under heat stress and the foliar application of four different biostimulants at 80 days after sowing (DAS) Each bar represents the mean of 10 plants $(n=10) \pm$ standard error. Bars followed by different letters indicate statistically significant differences according to the Tukey test $(\mathrm{P} \leq 0.05)$

C: control plants without heat stress $\left(28^{\circ} \mathrm{C}\right)$; HT: plants with a prolonged period (15 days) of high daytime temperatures $\left(40^{\circ} \mathrm{C}\right)$; BR: heat-stressed plants sprayed with brassinosteroids; AA: heat-stressed plants sprayed with amino acids; NP: heat-stressed plants sprayed with nitrophenolates; and BE: heat-stressed plants sprayed with botanical extracts 


\section{Leaf proline content and malondialdehyde (MDA) production}

Figure 4 shows the proline content and malondialdehyde (MDA) production. Differences between the rice genotypes ('F67' and ' $\mathrm{F} 60$ ') and biostimulant sprays were observed in the proline content $(P=0.0008)$ and MDA production $(P=0.0078)$ of rice plants under heat stress conditions at 80 DAS (Table 2). The highest values of these biochemical variables were recorded in plants of both genotypes under heat stress and without foliar application of biostimulants (HT), with mean values of $9.9 \mu \mathrm{mol} \cdot \mathrm{g}^{-1} \cdot \mathrm{FW}$ for proline and $12.4 \mu \mathrm{mol} \cdot \mathrm{g}$ '.FW for MDA. In contrast, the exogenous use of biostimulants (BR, AA, BE or NP) caused a reduction in the proline content of around 22\%, 34\%, 33\%, and 42\%, respectively, in ' $\mathrm{F} 67$ ' and ' $\mathrm{F} 60$ ' plants subjected to heat stress (Figure 4A). On the other hand, a decrease in lipid peroxidation (MDA) was also observed with the foliar application of BR, AA, BE or NP, with mean values of $8.4 \mu \mathrm{mol} \cdot \mathrm{g}^{-1} \cdot \mathrm{FW}$ and $10.5 \mu \mathrm{mol} \cdot \mathrm{g}^{-1} \cdot \mathrm{FW}$ for 'F 67 ' and 'F60' plants, respectively, under high daytime temperatures (Figure 4B). Finally, the accumulation of proline (mean values $4.3 \mu \mathrm{mol} \cdot \mathrm{g}^{-1} \cdot \mathrm{FW}$ ) and $\mathrm{MDA}$ (mean values $5.9 \mu \mathrm{mol} \cdot \mathrm{g}^{-1} \cdot \mathrm{FW}$ ) was always lower in plants without heat stress $(\mathrm{C})$ in both genotypes evaluated (Figures $4 \mathrm{~A}$ and $\mathrm{B}$ ).

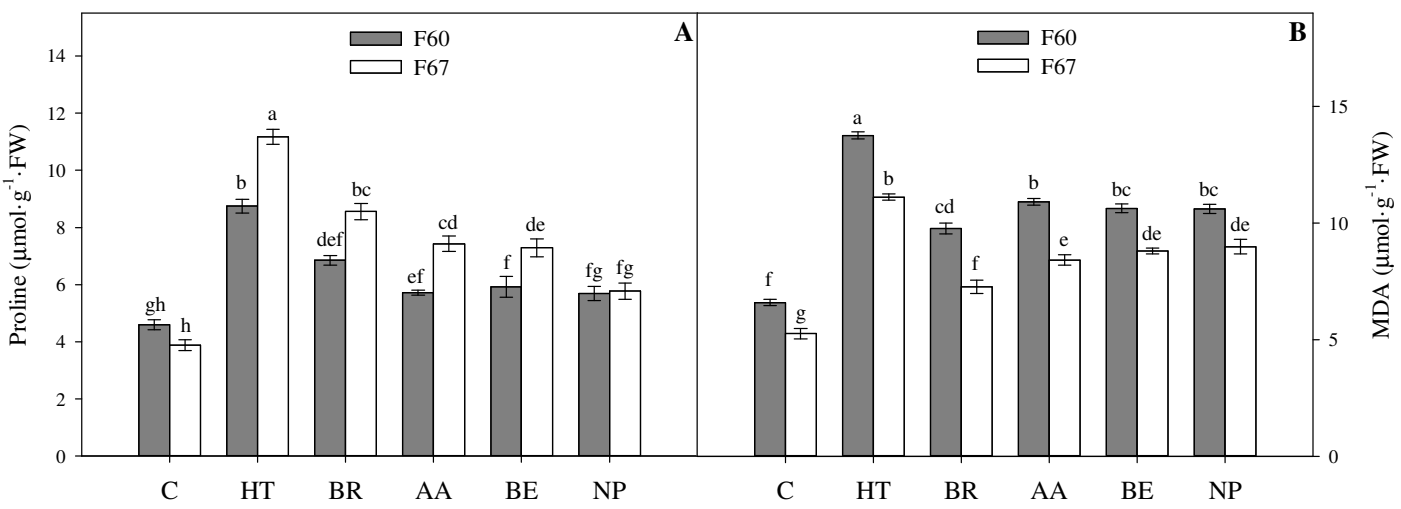

Figure 4. Proline content (A) and malondialdehyde (MDA) (B) production of rice plants (Oryza sativa L.) of the genotypes 'Fedearroz 67' ('F67') and 'Fedearroz 60' ('F60') under heat stress and foliar application of four different biostimulants at 80 days after sowing (DAS)

Each bar represents the mean of 10 plants $(n=10) \pm$ standard error. Bars followed by different letters indicate statistically significant differences according to the Tukey test $(\mathrm{P} \leq 0.05)$

C: control plants without heat stress $\left(28^{\circ} \mathrm{C}\right)$; HT: plants with a prolonged period (15 days) of high daytime temperatures $\left(40^{\circ} \mathrm{C}\right)$; BR: heat-stressed plants sprayed with brassinosteroids; AA: heat-stressed plants sprayed with amino acids; NP: heat-stressed plants sprayed with nitrophenolates; and BE: heat-stressed plants sprayed with botanical extracts

\section{Biplot analysis of physiological and biochemical responses to heat stress amelioration with biostimulant} sprays

The principal component analysis (PCA) showed that the evaluated variables explained $91.3 \%$ of the physiological response of the rice genotypes ('F67' and 'F60') under conditions of heat stress and foliar treatment with four different biostimulants at 80 DAS. In Figure 5, the vectors of the physiological $\left(\mathrm{P}_{N}, \mathrm{~g}_{s} E\right.$, $\mathrm{L}_{s}, \mathrm{P}_{N} / \mathrm{C}_{i}, \mathrm{WUE}_{i}$ ) and biochemical (TChl, MDA and proline) variables show angles close to the origin, which indicates that there is a high correlation between the plants' behaviour and these variables. Likewise, it was observed that plants of both genotypes under heat stress and without the application of biostimulants (HT) form a single group (I). It can be inferred that this group showed the highest effects due to the imposed heat stress condition. In contrast, the group of plants without the heat stress condition and biostimulant applications (C) (Group IV), was located in the sector opposite to group I. On the other hand, the foliar application of biostimulants showed two differential effects in the analysis: i) plants of both genotypes ('F67' and 'F60') with heat stress and foliar treatment with AA, BE or NP (Group II) displayed an intermediate behaviour, showing a slight positive effect of these biostimulants on heat stress mitigation; ii) plants of both 
genotypes ('F67' and 'F60') with heat stress and foliar treatment with BR (group III) displayed a positive effect on the physiological and biochemical response of plants, showing a behaviour close to group IV (C) (Figure 5).

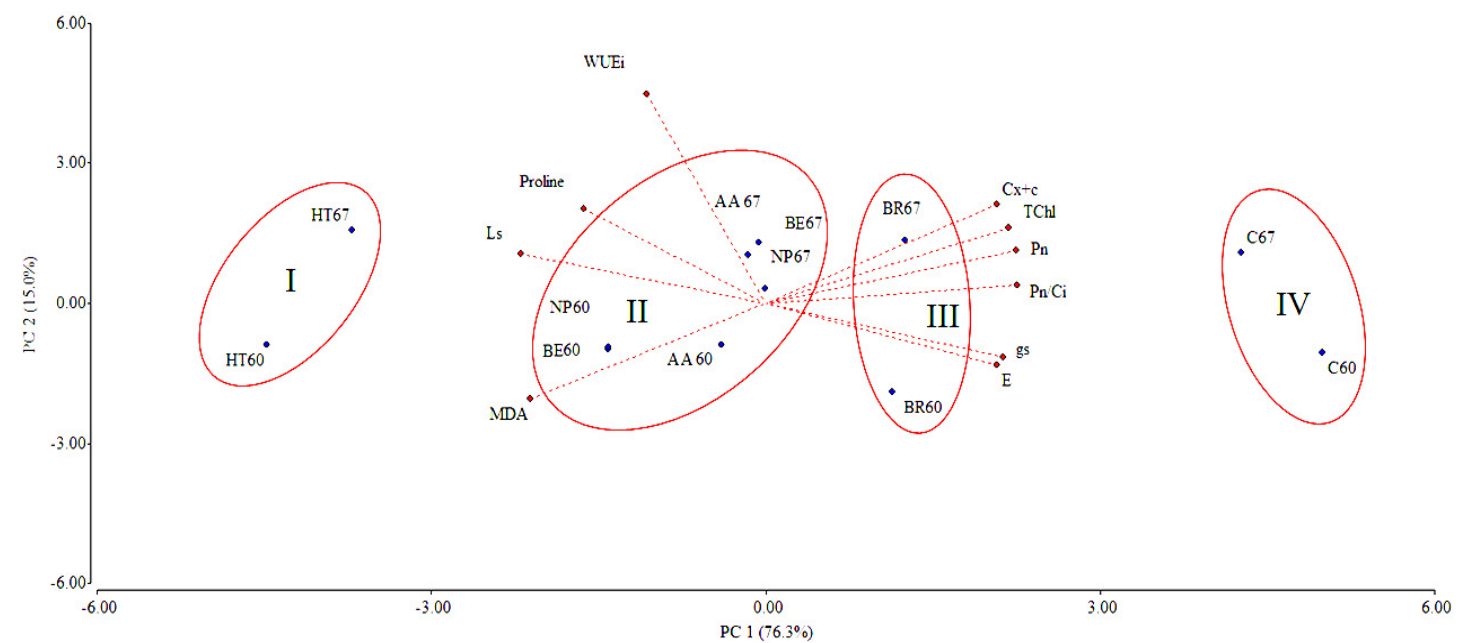

Figure 5. Principal component analysis (PCA) at 80 days after sowing (DAS) in rice plants (Oryza sativa L.) of the genotypes 'Fedearroz 67' ('F67') and 'Fedearroz 60' ('F60') under heat stress and foliar treatments with biostimulants

HT: plants subjected to heat stress without foliar application of biostimulants; C: control plants without heat stress conditions and foliar application of biostimulants; BR: heat-stressed plants sprayed with brassinosteroids; AA: heatstressed plants sprayed with amino acids; NP: heat-stressed plants sprayed with nitrophenolates; BE: heat-stressed plants sprayed with botanical extracts; $\mathrm{P}_{N}$ : net photosynthetic rate; $\mathrm{g}_{s:}$ stomatal conductance; $E$ : total transpiration; $\mathrm{L}_{s}$. stomatal limitations; $\mathrm{P}_{N} / \mathrm{C}_{i}$ : carboxylation efficiency; WUE: intrinsic water use efficiency; TChl: total chlorophyll; $\mathrm{Cx}+\mathrm{c}$ : carotenoids; MDA: malondialdehyde; PC: principal component.

\section{Heat tolerance coefficient (HTC)}

The heat tolerance coefficient (HTC) based on $\mathrm{P}_{N}$ also corroborated the observations of the biplot analysis. Foliar applications of the biostimulants BR, AA, BE, or NP help tolerate the stress caused by high temperatures in rice genotypes ' $\mathrm{F} 67$ ' and ' $\mathrm{F} 60$ '. The highest $\mathrm{HTC}$ values were observed in stressed plants of both genotypes and treated with foliar applications of $\mathrm{BR}(0.91$ for ' $\mathrm{F} 67$ ' and 0.76 for ' $\mathrm{F} 60$ '), followed by AA ( 0.84 for ' $\mathrm{F} 67$ ' and 0.74 for ' $\mathrm{F} 60$ '), NP ( 0.80 for ' $\mathrm{F} 67$ ' and 0.67 for ' $\mathrm{F} 60$ ') and BE ( 0.80 for ' $\mathrm{F} 67$ ' and 0.64 for ' $\mathrm{F} 60$ '). On the other hand, rice plants without application of biostimulants and subjected to high daytime temperatures showed the lowest values for 'F67' (0.59) and 'F60' (0.43) (Table 3).

\section{Correlation between physiological parameters and heat tolerance coefficient (HTC)}

Highly significant correlations were observed in the leaf gas exchange properties (plant transpiration $(E)$ and stomatal conductance $\left(\mathrm{g}_{s}\right)$ ) and total chlorophyll content (TChl) with the heat tolerance coefficient (HTC) in rice plants under heat stress conditions (Figure 6). A high positive correlation $\left(\mathrm{r}^{2}=0.92\right.$ and 0.96 , respectively) between $E$ and TChl and the HTC was registered in the rice genotype 'F60', with the highest values of $E$ and TChl in relation to the HTC in the treatments with foliar applications of BR or AA (Figures $6 \mathrm{~A}$ and $\mathrm{C}$ ). Regarding plants of genotype ' $\mathrm{F} 67$ ', the correlations also showed that the treatments with foliar applications of $\mathrm{BR}$ showed the highest values of $\mathrm{g}_{s}\left(\mathrm{r}^{2}=0.85\right)$ and $\mathrm{TChl}\left(\mathrm{r}^{2}=0.97\right)$ in relation to the HTC (Figures 6B and D). 

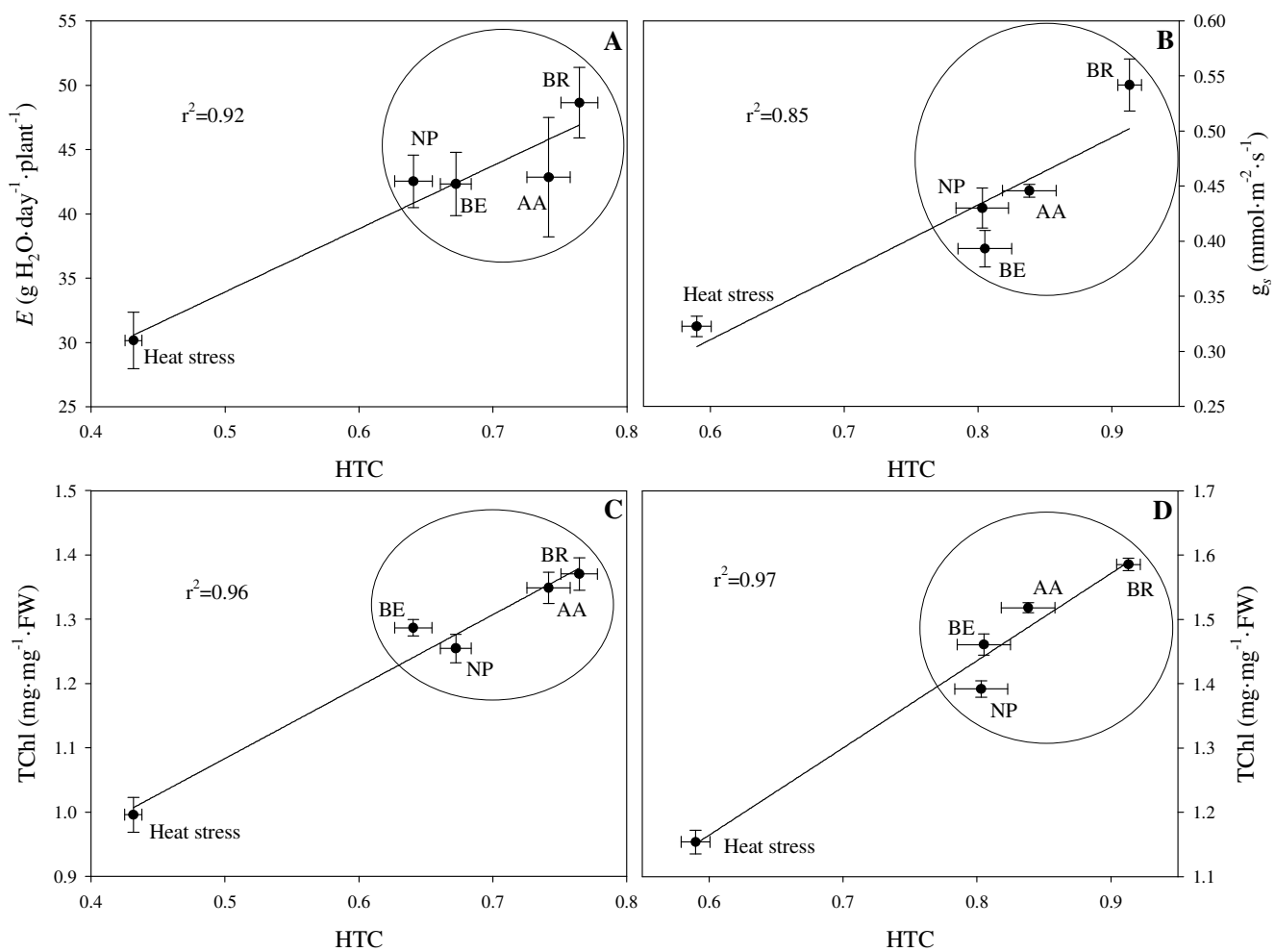

Figure 6. Correlation between plant transpiration $(E)(\mathrm{A})$, stomatal conductance $\left(\mathrm{g}_{s}\right)(\mathrm{B})$ or total content of chlorophyll (TChl) (C, D) and the heat tolerance coefficient (HTC) in rice plants (Oryza sativa L.) of the genotypes 'Fedearroz 60' (A, C) and 'Fedearroz 67' (B, D) under heat stress and foliar treatments with biostimulants at 80 days after sowing (DAS)

Each point represents the mean of ten plants. Vertical and horizontal bars represent \pm standard error per treatment $(n$ $=10$ ). Circles represent the group of treatments with the highest tolerance to heat stress

BR: heat-stressed plants sprayed with brassinosteroids; AA: heat-stressed plants sprayed with amino acids; NP: heatstressed plants sprayed with nitrophenolates; BE: heat-stressed plants sprayed with botanical extracts

Table 3. Effect of foliar applications of four biostimulants [brassinosteroids (BR), amino acids (AA), nitrophenolates (NP) or botanical extracts (BE)] on the heat tolerance coefficient (HTC) of rice plants (Oryza sativa L.) of the genotypes 'Fedearroz 67' and 'Fedearroz 60' exposed to a prolonged period (15 days) of heat stress $\left(40^{\circ} \mathrm{C}\right)$ at 80 days after sowing (DAS)

\begin{tabular}{|c|c|c|}
\hline Genotype & Biostimulant & HTC \\
\hline \multirow{5}{*}{ 'Fedearroz 60' } & Heat stress & $0.43 \mathrm{~g}^{\mathrm{Z}}$ \\
\hline & $\mathrm{BR}$ & $0.76 \mathrm{c}$ \\
\hline & $\mathrm{AA}$ & $0.74 \mathrm{~cd}$ \\
\hline & $\mathrm{BE}$ & $0.64 \mathrm{ef}$ \\
\hline & NP & $0.67 \mathrm{de}$ \\
\hline \multirow{5}{*}{ 'Fedearroz 67' } & Heat stress & $0.59 \mathrm{f}$ \\
\hline & $\mathrm{BR}$ & $0.91 \mathrm{a}$ \\
\hline & $\mathrm{AA}$ & $0.84 \mathrm{~b}$ \\
\hline & $\mathrm{BE}$ & $0.80 \mathrm{bc}$ \\
\hline & NPs & $0.80 \mathrm{bc}$ \\
\hline \multicolumn{2}{|c|}{$\mathrm{P}$-value } & 0.000 \\
\hline \multicolumn{2}{|c|}{$\mathrm{CV}(\%)^{\mathrm{Y}}$} & 4.69 \\
\hline
\end{tabular}

${ }^{\mathrm{Z}}$ Data represent the mean of ten plants per treatment $(n=10)$. Means followed by the same letter do not show significant differences at $P \leq 0.05 .{ }^{\mathrm{Y}} \mathrm{CV}$ : Coefficient of variation. 


\section{Discussion}

This study showed that plants of both rice genotypes ('F67' and 'F60') without the application of biostimulants and under conditions of heat stress (HT) showed physiological effects such as a reduction in the leaf gas exchange properties $\left(\mathrm{P}_{N}, \mathrm{~g}_{s}\right.$, and $\left.E\right)$, low leaf chlorophyll content, and increased MDA and proline contents (Figures 1-4). Abiotic stress due to high daytime temperatures causes adverse effects on physiological and biochemical parameters that affect the growth and development of cultivable plants (Fahad et al., 2017; Wassie et al., 2019). Exposure of plants to high-temperature stress decreases the exchange properties and the concentration of leaf photosynthetic pigments (total chlorophyll (TChl) and carotenoids $(\mathrm{Cx}+\mathrm{c}))(\mathrm{Chen}$ et al., 2017b; Ahammed et al., 2018). Heat stress also affects the integrity of the membrane (higher lipid peroxidation (MDA)) and causes an increase in the accumulation of compatible solutes such as proline (Harsh et al., 2016; Ahammed et al., 2018). These physiological and biochemical variables have been used for phenotyping or evaluating management strategies to confer tolerance to rice genotypes under periods of heat stress (Restrepo-Diaz and Garces-Varon, 2013; Sánchez-Reinoso et al., 2014; Sharma et al., 2017).

Agronomic management practices such as the foliar application of biostimulants have been used to improve plant tolerance responses, since they can regulate and/or modify physiological and biochemical processes in plants to stimulate growth, mitigate the limitations induced by abiotic stress and increase yield (Bulgari et al., 2019; Drobek et al., 2019). Our results showed that foliar applications of biostimulants (BR, $\mathrm{AA}, \mathrm{NP}$, or BE) helped to mitigate the negative effects caused by heat stress conditions by favouring the physiological and biochemical responses in seedlings of both rice genotypes (Table 3; Figures 1-6). The beneficial role of foliar sprays of these compounds on the physiological and biochemical parameters of plants under periods of high diurnal temperatures has been widely documented for BR in rice (Thussagunpanit et al., 2015a; Sonjaroon et al., 2018), AA in maize (Matysiak et al., 2020) and mung bean (Priya et al., 2019), NP in soybean (Gulluoglu et al., 2006), and BE in tomato (Carmody et al., 2020).

In this study, it was observed that BR mitigated the negative effects of heat stress in rice genotypes 'F67' and 'F60', through an improvement in the gas exchange parameters and biochemical markers, and increased the heat tolerance coefficient (HTC). Sonjaroon et al. (2018) also observed that rice plants with foliar BR treatments and under heat stress showed an increase in physiological variables such as $\mathrm{P}_{N}, \mathrm{~g}_{s}, E$ and $\mathrm{L}_{s}$ compared to plants without BR application. It has been reported that BR can induce and improve thermotolerance in both heat-tolerant and heat-susceptible genotypes (Ahammed et al., 2020). The positive response on the gas exchange parameters of plants under heat stress conditions may be associated with the fact that BR participate in the accumulation of carbon metabolites such as soluble sugars, starch or sucrose, and the induction of chlorophyll biosynthesis (Sadura and Janeczko, 2018; Tanveer, 2019). On the other hand, BR applications decreased lipid peroxidation (MDA) values and proline content, since this plant hormone regulates the activity of antioxidant enzymes (ascorbate peroxidase (APX), catalase (CAT), superoxide dismutase (SOD), glutathione reductase (GR), dehydroascorbate reductase (DHAR) and monodehydroascorbate reductase (MDHAR)) and favours the expression of stress response genes that can encode phytochelatins, osmolytes, organic acids, metallothioneins, and heat shock proteins (HSP) (Rajewska et al., 2016).

Foliar applications of AA (arginine, proline, tryptophan, glycine, and cysteine) also favoured gas exchange parameters $\left(\mathrm{P}_{N}, \mathrm{~g}_{s}, E, \mathrm{~L}_{s}, \mathrm{P}_{N} / \mathrm{C}_{i}\right.$ and $\left.\mathrm{WUE}_{i}\right)$ in plants of genotypes ' $\mathrm{F} 67$ ' and ' $\mathrm{F} 60$ ' under heat stress conditions. The positive effect of foliar AA applications in creeping bentgrass (Agrostis stolonifera) plants has been reported, improving $\mathrm{P}_{N}, \mathrm{~g}_{s}, E$, and relative water content under heat stress conditions (Li et al., 2016). AA help to mitigate the effects of stress caused by high daytime temperatures because they participate in the metabolism of nitrogen and the balance of the $\mathrm{C} / \mathrm{N}$ ratio (Price et al., 2012). Additionally, these compounds favor the synthesis of glutamate receptors (GLRs), which help mediate processes such as accumulation of soluble sugars, stomatal movements (stomatal opening), and stimulation of photosynthesis (Teixeira et al., 2018). On the other hand, the exogenous application of AA (arginine, proline, tryptophan, glycine, and cysteine) in plants under conditions of heat stress also increased the content of leaf photosynthetic pigments 
(TChl and $\mathrm{Cx}+\mathrm{c}$ ) and decreased the concentration of MDA and proline. Vijayakumaril and Puthur (2016) also found that the application of AA $\gamma$-aminobutyric acid caused a significant decrease in the proline content in pepper (Piper nigrum L.) plants under conditions of heat stress. Regarding oxidative damage, the mitigating effect of foliar applications of AA in rice plants could be because these compounds participate in the biosynthesis of chlorophyll (Ali et al., 2019), regulation of the activity of antioxidant enzymes such as SOD, CAT, APX and GR and the accumulation of non-enzymatic antioxidants (ascorbic acid (AsA) and glutathione (GSH)) (Li et al., 2016).

The exogenous use of NP helped the evaluated physiological and biochemical parameters of rice genotypes exposed to a high daytime temperature condition. Przybysz et al. (2014) observed that foliar applications of NP also caused an increase in the photosynthetic efficiency, $E$ and water uptake, and a decrease in the stomatal resistance of Arabidopsis thaliana L. plants under drought conditions. Likewise, Djanaguiraman et al. (2009) reported that cotton (Gossypium hirsutum L.) plants treated with a commercial product based on NP (Atonik) also had lower lipid peroxidation of membranes (MDA) and a higher TChl during the leaf senescence process (oxidative stress). Additionally, Swaefy and El-Ziat (2017) concluded that foliar applications of NP decreased proline values in calendula (Calendula officinalis) plants under salinity conditions. It has been reported that NP can increase the photosynthetic plant capacity by reducing stomatal resistance, guaranteeing a more effortless and higher flow of $\mathrm{CO}_{2}$ to the chloroplast, increasing the maximum photochemical efficiency of PSII, and promoting chlorophyll biosynthesis or slowing down its degradation (Przybysz et al., 2014; Kazda et al., 2015). These compounds are also involved in the capture of free radicals by phenolic compounds (inhibiting lipid and protein oxidation) and ROS scavenging through increased peroxidase activity (Djanaguiraman et al., 2010; Szparaga et al., 2018).

$\mathrm{BE}$ applications on plants of both rice genotypes ('F67' and 'F60') under conditions of stress caused by high daytime temperatures decreased the adverse effects on gas exchange parameters. Rashid et al. (2018) recorded that quinoa plants treated with Moringa oleifera $\mathrm{BE}$ increased gas exchange parameters $\left(\mathrm{P}_{N}\right.$ and $\left.\mathrm{g}_{s}\right)$ and water use efficiency under heat stress conditions. This positive response may be associated with the fact that $\mathrm{BE}$ are rich in glycine betaine, which delays the loss of photosynthetic activity by inhibiting chlorophyll degradation. Additionally, they participate in chlorophyll biosynthesis and regulate $S$ and $\mathrm{N}$ metabolism (Jannin et al., 2013; Yao et al., 2020). BE also caused lower lipid peroxidation and proline synthesis, and a higher concentration of leaf photosynthetic pigments in heat-stressed plants. Zhang and Ervin (2008) and Zhang et al. (2010) observed that applications based on seaweed BE promoted higher TChl values and a lower concentration of MDA in creeping bentgrass (Agrostis stolonifera L.) plants subjected to moderate periods of heat stress (>14 days). BE have been reported to help plants under abiotic stress because they improve enzymatic activity (SOD, APX, and CAT) and non-enzymatic antioxidant metabolism, such as phenolic compounds. They also favor the primary metabolism of plants by increasing the levels of free amino acids, proteins, carbohydrates, and leaf photosynthetic pigments (Mansori et al., 2016; Santaniello et al., 2017; Yakhin et al., 2017). This was observed in the present study with a higher content of TChl and Cx+c and lower lipid peroxidation of membranes (MDA).

Finally, the positive effects of the foliar application of the different biostimulants used (BR, AA, NP or $\mathrm{BE}$ ) on rice plants ('F67' and ' $\mathrm{F} 60$ ') under conditions of high temperatures during the day are the result of the combination of physiological $\left(\mathrm{P}_{N}, \mathrm{~g}_{,}, E, \mathrm{~L}_{s}, \mathrm{P}_{N} / \mathrm{C}_{i}\right.$ and $\left.\mathrm{WUE}_{i}\right)$ and biochemical (TChl, $\mathrm{Cx}+\mathrm{c}, \mathrm{MDA}$ and proline) attributes which are reflected in a higher HTC (Table 3). This indicates that these biostimulants are signaling molecules that can interact with cellular transcription factors to regulate different physiological and biochemical processes involved in tolerance to abiotic stress conditions in plants (Van Oosten et al., 2017; Bulgari et al., 2019; Kerchev et al., 2020). 


\section{Conclusions}

In the current study, the results obtained in this study showed that biostimulants' foliar application (BR, AA, NP, or BE) helped to ameliorate the negative effects of heat stress in rice genotypes 'F67' and 'F60'. Foliar applications of biostimulants helped the leaf gas exchange parameters (net photosynthesis, stomatal conductance, total transpiration, carboxylation efficiency, and water use efficiency), and concentration of leaf photosynthetic pigments (chlorophylls and carotenoids). The use of these biostimulants also showed a significant reduction in the lipid peroxidation of membranes (MDA) and proline content, suggesting an antioxidant activity in rice plants subjected to heat stress. This research allows us to conclude that BR, AA, NP or $\mathrm{BE}$ are compounds that can generate a beneficial effect on rice plants under conditions of heat stress. Foliar applications of these biostimulants can be considered an agronomic strategy to mitigate the adverse effects caused by heat stress conditions in rice-producing areas where episodes of increases in mean daytime temperatures could be expected.

\section{Authors' Contributions}

Conceptualization: GGV and HRD; Data curation: CCCA and HRD; Formal Analysis: CCCA and HRD; Funding acquisition: GGV and HRD; Investigation: EHQC and ADSR; Methodology: EHQC, ADSR and HRD; Project administration; ADSR and HRD; Resources: GGV; Software: ADSR and HRD; Supervision: ADSR and HRD; Validation: EHQC and ADSR; Visualization: EHQC and CCCA; Writing original draft: CCCA; Writing - review and editing: GGV and HRD. All authors read and approved the final manuscript.

\section{Acknowledgements}

This research received no specific grant from any funding agency in the public, commercial, or not-forprofit sectors.

\section{Conflict of Interests}

The authors declare that there are no conflicts of interest related to this article.

\section{References}

Ahammed GJ, Xu W, Liu A, Chen S (2018). COMT1 silencing aggravates heat stress induced reduction in photosynthesis by decreasing chlorophyll content, photosystem II activity, and electron transport efficiency in tomato. Frontiers in Plant Science 9:998. https://doi.org/10.3389/fpls.2018.00998

Ahammed GJ, Li X, Liu A, Chen S (2020). Brassinosteroids in plant tolerance to abiotic stress. Journal of Plant Growth Regulation 1:4. https://doi.org/10.1007/s00344-020-10098-0

Ahanger MA, Ashraf M, Bajguz A, Ahmad P (2018). Brassinosteroids regulate growth in plants under stressful environments and crosstalk with other potential phytohormones. Journal of Plant Growth Regulation 37:10071024. https://doi.org/10.1007/s00344-018-9855-2

Ali Q, Athar HB, Haider MZ, Shahid S, Aslam N, Shehzad F, ... Hussain SM (2019). Role of amino acids in improving abiotic stress tolerance to plants. In: Hasanuzzaman M, Fujita M, Oku H, Islam MT (Eds). Plant Tolerance to Environmental Stress: Role of Phytoprotectants. CRC Press, Boca Raton, pp 175-203. 
Anwar A, Liu Y, Dong R, Bai L, Yu X, Li Y (2018). The physiological and molecular mechanism of brassinosteroid in response to stress: a review. Biological Research 51:46. https://doi.org/10.1186/s40659-018-0195-2

Bahuguna RN, Solis CA, Shi WJ, Jagadish KSV (2017). Post-flowering night respiration and altered sink activity account for high night temperature-induced grain yield and quality loss in rice (Oryza sativa L.). Physiologia Plantarum 159(1):59-73. https://doi.org/10.1111/ppl.12485

Baninasab B, Ghobadi C (2011). Influence of paclobutrazol and application methods on high-temperature stress injury in cucumber seedlings. Journal of Plant Growth Regulation 30(2):213-219. https://doi.org/10.1007/s00344$010-9188-2$

Bates LS, Waldren RP, Teare ID (1973). Rapid determination of free proline for water-stress studies. Plant and Soil 39:205-207. https://doi.org/10.1007/BF00018060

Botta A (2013). Enhancing plant tolerance to temperature stress with amino acids: an approach to their mode of action. Acta Horticulturae 1009:29-35. https://doi.org/10.17660/ActaHortic.2013.1009.1

Bulgari R, Cocetta G, Trivellini A, Vernieri P, Ferrante A (2015). Biostimulants and crop responses: a review. Biological Agriculture \& Horticulture 31:1-17. https://doi.org/10.1080/01448765.2014.964649

Bulgari R, Franzoni G, Ferrante A (2019). Biostimulants application in horticultural crops under abiotic stress conditions. Agronomy 9(6):306. https://doi.org/10.3390/agronomy9060306

Carmody N, Goñi O, Łangowski Ł, O’Connell S (2020). Ascophyllum nodosum extract biostimulant processing and its impact on enhancing heat stress tolerance during tomato fruit set. Frontiers in Plant Science 11:807. https://doi.org/10.3389/fpls.2020.00807

Chen J, Tang L, Shi P, Yang B, Sun T, Cao W, Zhu Y (2017a). Effects of short-term high temperature on grain quality and starch granules of rice (Oryza sativa L.) at post-anthesis stage. Protoplasma 254:935-943. https://doi.org/10.1007/s00709-016-1002-y

Chen Q, Zhao X, Lei D, Hu S, Shen Z, Shen W, Xu X (2017b). Hydrogen-rich water pretreatment alters photosynthetic gas exchange, chlorophyll fluorescence, and antioxidant activities in heat-stressed cucumber leaves. Plant Growth Regulation 83:69-82. http://dx.doi.org/10.1007\%2Fs10725-017-0284-1

Counce PA, Keisling TC, Mitchell AJ (2000). A uniform, objective, and adaptive system for expressing rice development. Crop Science 40:436-443. https://doi.org/10.2135/cropsci2000.402436x

Djanaguiraman M, Sheeba JA, Devi DD, Bangarusamy U (2009). Cotton leaf senescence can be delayed by nitrophenolate spray through enhanced antioxidant defense system. Journal of Agronomy and Crop Science 195:213-224. https://doi.org/10.1111/j.1439-037X.2009.00360.X

Djanaguiraman M, Sheeba JA, Devi DD, Bangarusamy U, Prasad PVV (2010). Nitrophenolates spray can alter boll abscission rate in cotton through enhanced peroxidase activity and increased ascorbate and phenolics levels. Journal of Plant Physiology 167:1-9. https://doi.org/10.1016/j.jplph.2009.05.018

Drobek M, Frąc M, Cybulska J (2019). Plant biostimulants: importance of the quality and yield of horticultural crops and the improvement of plant tolerance to abiotic stress-a review. Agronomy 9:335. https://doi.org/10.3390/agronomy9060335

du Jardin P (2015). Plant biostimulants: definition, concept, main categories and regulation. Scientia Horticulturae 196:3-14. https://doi.org/10.1016/j.scienta.2015.09.021

Fahad S, Bajwa AA, Nazir U, Anjum SA, Farooq A, Zohaib A, ... Huang J (2017). Crop production under drought and heat stress: plant responses and management options. Frontiers in Plant Science 8:1147. http://dx.doi.org/10.3389/fpls.2017.01147

Fan YH, Ma CX, Huang ZL, Abid M, Jiang SY, Dai TB, ... Han X (2018). Heat priming during early reproductive stages enhances thermo-tolerance to post-anthesis heat stress via improving photosynthesis and plant productivity in winter wheat (Triticum aestivum L.). Frontiers in Plant Science 9:805. https://doi.org/10.3389/fpls.2018.00805

Farooq M, Rizwan M, Nawaz A, Rehman A, Ahmad R (2017). Application of natural plant extracts improves the tolerance against combined terminal heat and drought stresses in bread wheat. Journal of Agronomy and Crop Science 203:528-538. https://doi.org/10.1111/jac.12214

Federarroz (Federación Nacional de Arroceros) (2019). On line statistical database: Area, production and yields in Colombia. Retrieved 2020 September 30 from http://www.fedearroz.com.co/new/apr_public.php

Flexas J, Gulías J, Jonasson S, Medrano H, Mus M (2001). Seasonal patterns and control of gas exchange in local populations of the Mediterranean evergreen shrub Pistacia lentiscus L. Acta Oecologica 22:33-43. https://doi.org/10.1016/S1146-609X(00)01099-7 
Francesca S, Arena C, Hay Mele B, Schettini C, Ambrosino P, Barone A, Rigano MM (2020). The use of a plant-based biostimulant improves plant performances and fruit quality in tomato plants grown at elevated temperatures. Agronomy 10(3):363. https://doi.org/10.3390/agronomy10030363

Garces-Varón G, Puentes OM (2019). Efecto de la condición de luminosidad sobre el comportamiento de nuevas variedades de arroz [Effect of the light condition on the behavior of new rice varieties]. Revista Arroz 67:10-16.

Garcés-Varon G, Restrepo-Díaz H (2015). Growth and yield of rice cultivars sowed on different dates under tropical conditions. Ciencia e investigación agraria 42(2):217-226. http://dx.doi.org/10.4067/S071816202015000200008

Gulluoglu L, Arioglu H, Arslan M (2006). Effects of some plant growth regulators and nutrient complexes on aboveground biomass and seed yield of soybean grown under heat-stressed environment. Journal of Agronomy 5(1):126-130.

Harsh A, Sharma YK, Joshi U, Rampuria S, Singh G, Kumar S, Sharma R (2016). Effect of short-term heat stress on total sugars, proline and some antioxidant enzymes in moth bean (Vigna aconitifolia). Annals of Agricultural Sciences 61:57-64. https://doi.org/10.1016/j.aoas.2016.02.001

Hatfield JL, Prueger JH (2015). Temperature extremes: effect on plant growth and development. Weather and Climate Extremes 10:4-10. https://doi.org/10.1016/j.wace.2015.08.001

Hirabayashi H, Sasaki K, Kambe T, Gannaban RB, Miras MA, Mendioro MS, ... Ishimaru T (2014). qEMF3, a novel QTL for the early-morning flowering trait from wild rice, Oryza officinalis, to mitigate heat stress damage at flowering in rice, $O$. sativa L. Journal of Experimental Botany 66:1227-1236. https://doi.org/10.1093/jxb/eru474

Hodges DM, DeLong JM, Forney CF, Prange RK (1999). Improving the thiobarbituric acid-reactive-substances assay for estimating lipid peroxidation in plant tissues containing anthocyanin and other interfering compounds. Planta 207:604-611. https://doi.org/10.1007/s004250050524

Hussain HA, Men S, Hussain S, Chen Y, Ali S, Ali S, ... Wang L (2019). Interactive effects of drought and heat stresses on morpho-physiological attributes, yield, nutrient uptake and oxidative status in maize hybrids. Scientific Reports 9:3890. https://doi.org/10.1038/s41598-019-40362-7

IPCC (2014). Climate Change 2014: Synthesis Report. In: Pachauri RK and Meyer LA (Eds). Core Writing Team, Contribution of Working Groups I, II and III to the Fifth Assessment Report of the Intergovernmental Panel on Climate Change. IPCC, Geneva, Switzerland, pp 151.

Jannin L, Arkoun M, Etienne P, Laîné P, Goux D, Garnica M, ... Ourry A (2013). Brassica napus growth is promoted by Ascophyllum nodosum (L.) Le Jol. seaweed extract: microarray analysis and physiological characterization of N, C, and S metabolisms. Journal of Plant Growth Regulation 32:31-52. https://doi.org/10.1007/s00344-0129273-9

Kazda J, Herda G, Spitzer T, Ričařová V, Przybysz A, Gawrońska H (2015). Effect of nitrophenolates on pod damage caused by the brassica pod midge on the photosynthetic apparatus and yield of winter oilseed rape. Journal of Pest Science 88:235-247. https://doi.org/10.1007/s10340-014-0603-5

Kerchev P, Van Der Meer T, Sujeeth N, Verlee A, Stevens CV, Van Breusegem F, Gechev T (2020). Molecular priming as an approach to induce tolerance against abiotic and oxidative stresses in crop plants. Biotechnology Advances 40:107503. https://doi.org/10.1016/j.biotechadv.2019.107503

Kilasi NL, Singh J, Vallejos CE, Ye C, Jagadish SV, Kusolwa P, Rathinasabapathi B (2018). Heat stress tolerance in rice (Oryza sativa L.): Identification of quantitative trait loci and candidate genes for seedling growth under heat stress Frontiers in Plant Science 9:1578. https://doi.org/10.3389/fpls.2018.01578

Li Z, Yu J, Peng Y, Huang B (2016). Metabolic pathways regulated by g-aminobutyric acid (GABA) contributing to heat tolerance in creeping bentgrass (Agrostis stolonifera). Scientific Reports 6:30338. https://doi.org/10.1038/srep30338

Liu YZ, Bin T, Zheng YL, Xu SZ, Qiu FZ (2010). Screening methods for waterlogging tolerance at maize (Zea mays L.) seedling stage. Agricultural Sciences in China 9:362-369. https://doi.org/10.1016/S1671-2927(09)60105-X

Lucini L, Rouphael Y, Cardarelli M, Canguier R, Kumar P, Colla G (2015). The effect of a plant-derived biostimulant on metabolic profiling and crop performance of lettuce grown under saline conditions. Scientia Horticulturae 182:124-133. https://doi.org/10.1016/j.scienta.2014.11.022

Mansori M, Chernane H, Latique S, Benaliat A, Hsissou D, El Kaoua M (2016). Effect of seaweed extract (Ulva rigida) on the water deficit tolerance of Salvia officinalis L. Journal of Applied Phycology 28(2):1363-1370. https://doi.org/10.1007/s10811-015-0671-9 
Matysiak K, Kierzek R, Siatkowski I, Kowalska J, Krawczyk R (2020). Effect of exogenous application of amino acids 1arginine and glycine on maize under temperature stress. Agronomy 10(6):769. https://doi.org/10.3390/agronomy10060769

Nguyen HC., Lin KH, Ho SL, Chiang CM, Yang CM (2018). Enhancing the abiotic stress tolerance of plants: from chemical treatment to biotechnological approaches. Physiologia Plantarum 164:452-466. https://doi.org/10.1111/ppl.12812

Nigam D, Kumar S, Mishra DC, Rai A, Smita S, Saha A (2015). Synergistic regulatory networks mediated by microRNAs and transcription factors under drought, heat and salt stresses in Oryza sativa spp. Gene 555(2):127-139. https://doi.org/10.1016/j.gene.2014.10.054

Povero G, Mejia JF, Di Tommaso D, Piaggesi A, Warrior P (2016). A systematic approach to discover and characterize natural plant biostimulants. Frontiers in Plant Science 7:435. https://doi.org/10.3389/fpls.2016.00435

Price MB, Jelesko J, Okumoto S. 2012. Glutamate receptor homologs in plants: functions and evolutionary origins. Frontiers in Plant Science 3:235. https://doi.org/10.3389/fpls.2012.00235

Priya M, Sharma L, Kaur R, Bindumadhava H, Nair RM, Siddique KHM, Nayyar H (2019). GABA ( $\gamma$-aminobutyric acid), as a thermo-protectant, to improve the reproductive function of heat-stressed mungbean plants. Scientific Reports 9:7788. https://doi.org/10.1038/s41598-019-44163-W

Przybysz A, Gawronska H, Gajc-wolska J (2014). Biological mode of action of anitrophenolates-based biostimulant: case study. Frontiers in Plant Science 5:713. https://doi.org/10.3389/fpls.2014.00713

Radhakrishna NKA., Chenniappan V, Dhashnamurthi V (2018). Combined effects of drought and moderately high temperature on the photosynthesis, PS II photochemistry and yield traits in rice (Oryza sativa L.). Indian Journal of Plant Physiology 23(3):408-415. https://doi.org/10.1007/s40502-018-0386-4

Rajewska I, Talarek M, Bajguz A (2016). Brassinosteroids and response of plants to heavy metals action. Frontiers in Plant Science 7:629. https://doi.org/10.3389/fpls.2016.00629

Ramirez-Villegas J, Salazar M, Jarvis A, Navarro-Racines CE (2012). A way forward on adaptation to climate change in Colombian agriculture: perspectives towards 2050. Climatic Change 115:611-628. http://dx.doi.org/10.1007/s10584-013-0731-6

Rashid N, Basra SM, Shahbaz M, Iqbal S, Hafeez MB (2018). Foliar applied moringa leaf extract induces terminal heat tolerance in quinoa. International Journal of Agriculture and Biology 20:157-164. https://dx.doi.org/10.17957/IJAB/15.0469

Restrepo-Díaz H. Garces-Varon G (2013). Response of rice plants to heat stress during initiation of panicle primordia or grain-filling phases. Journal of Stress Physiology \& Biochemistry 9:319-325.

Sadura I, Janeczko A (2018). Physiological and molecular mechanisms of brassinosteroid-induced tolerance to high and low temperature in plants. Biologia Plantarum 64:601-616. https://doi.org/10.1007/s10535-018-0805-4

Sahu GK (2013). Salicylic acid: role in plant physiology and stress tolerance. In: Rout GR, Das AB (Eds). Molecular Stress Physiology of Plants. Springer, India, pp 217-239.

Sánchez-Reinoso AD, Garces-Varon G, Restrepo-Diaz H. 2014. Biochemical and physiological characterization of three rice cultivars under different daytime temperature conditions. Chilean Journal of Agricultural Research 74:373379. http://dx.doi.org/10.4067/S0718-58392014000400001

Santaniello A, Scartazza A, Gresta F, Loreti E, Biasone A, Di Tommaso D, ... Perata P (2017). Ascophyllum nodosum seaweed extract alleviates drought stress in Arabidopsis by affecting photosynthetic performance and related gene expression. Frontiers in Plant Science 8:1362. https://doi.org/10.3389/fpls.2017.01362

Sharma I, Kaur N, Pati PK (2017). Brassinosteroids: a promising option in deciphering remedial strategies for abiotic stress tolerance in rice. Frontiers in Plant Science 8:2151. https://doi.org/10.3389/fpls.2017.02151

Shin H, Oh S, Arora R, Kim D (2016). Proline accumulation in response to high temperature in winter-acclimated shoots of Prunus persica: a response associated with growth resumption or heat stress?. Canadian Journal of Plant Science 96(4):630-638. https://doi.org/10.1139/cjps-2015-0372

Sims DA, Gamon JA (2002). Relationships between leaf pigment content and spectral reflectance across a wide range of species, leaf structures and developmental stages. Remote Sensing of Environment 81:337-354. https://doi.org/10.1016/S0034-4257(02)00010-X

Sonjaroon W, Jutamanee K, Khamsuk O, Thussagunpanit J, Kaveeta L, Suksamrarn A (2018). Impact of brassinosteroid mimic on photosynthesis, carbohydrate content and rice seed set at reproductive stage under heat stress. Agriculture and Natural Resources 52(3):234-240. https://doi.org/10.1016/j.anres.2018.09.001 
Swaefy HM, El-Ziat RA (2017). Response of double-flowered Marigold to salinity and biostimulant applications. Middle East Journal of Agriculture Research 6(4):1519-1525.

Szparaga A, Kocira S, Kocira A, Czerwińska E, Świeca M, Lorencowicz E, ... Oniszczuk T (2018). Modification of growth, yield, and the nutraceutical and antioxidative potential of soybean through the use of synthetic biostimulants. Frontiers in Plant Science 9:1401. https://doi.org/10.3389/fpls.2018.01401

Tanveer M (2019). Role of 24-Epibrassinolide in inducing thermo-tolerance in plants. Journal of Plant Growth Regulation 38:945-955. https://doi.org/10.1007/s00344-018-9904-X

Teixeira WF, Fagan EB, Soares LH, Soares JN, Reichardt K, Neto DD (2018). Seed and foliar application of amino acids improve variables of nitrogen metabolism and productivity in soybean crop. Frontiers in Plant Science 9:396. https://doi.org/10.3389/fpls.2018.00396

Thussagunpanit J, Jutamanee K, Kaveeta L, Chai-arree W, Pankean P, Homvisasevongsa S, Suksamrarn A (2015a). Comparative effects of brassinosteroid and brassinosteroid mimic on improving photosynthesis, lipid peroxidation, and rice seed set under heat stress. Journal of Plant Growth Regulation 34(2):320-331. https://doi.org/10.1007/s00344-014-9467-4

Thussagunpanit J, Jutamanee K, Sonjaroon W, Kaveeta L, Chai-Arree W, Pankean P, Suksamrarn A (2015b). Effects of brassinosteroid and brassinosteroid mimic on photosynthetic efficiency and rice yield under heat stress. Photosynthetica 53:312-320. https://doi.org/10.1007/s11099-015-0106-5

Valero D, Zapata PJ, Martínez-Romero D, Guillén F, Castillo S, Serrano M (2014). Pre-harvest treatments of pepper plants with nitrophenolates increase crop yield and enhance nutritive and bioactive compounds in fruits at harvest and during storage. Food Science and Technology International 20(4):265-274. https://doi.org/10.1177\%2F1082013213483137

Van Oosten MJ, Pepe O, Pascale S, de Silletti S, Maggio A (2017). The role of biostimulants and bioeffectors as alleviators of abiotic stress in crop plants. Chemical and Biological Technologies in Agriculture 4:5. https://doi.org/10.1186/s40538-017-0089-5

Vijayakumari K, Puthur JT (2016). g-Aminobutyric acid (GABA) priming enhances the osmotic stress tolerance in Piper nigrum Linn: plants subjected to PEG-induced stress. Plant Growth Regulation 78:57-67. https://doi.org/10.1007/s10725-015-0074-6

Vivitha P, Raveendran M, Vijayalakshmi C, Vijayalakshmi D (2018). Genetic dissection of high temperature stress tolerance using photosynthesis parameters in QTL introgressed lines of rice cv. Improved White Ponni. Indian Journal of Plant Physiology 23(4):741-747. https://doi.org/10.1007/s40502-018-0408-2

Wang K, Wambugu PW, Zhang B, Wu AC, Henry RJ, Gilbert RG (2015). The biosynthesis, structure and gelatinization properties of starches from wild and cultivated African rice species (Oryza barthii and Oryza glaberrima). Carbohydrate Polymers 129:92-100. https://doi.org/10.1016/j.carbpol.2015.04.035

Wang YL, Wang L, Zhou JX, Hu SB, Chen HZ, Xiang J, ... Zhang YP (2019). Research progress on heat stress of rice at flowering stage. Rice Science 26:1-10. https://doi.org/10.1016/j.rsci.2018.06.009

Wassie M, Zhang W, Zhang Q, Ji K, Chen L (2019). Effect of heat stress on growth and physiological traits of alfalfa (Medicago sativa L.) and a comprehensive evaluation for heat tolerance. Agronomy 9(10):597. https://doi.org/10.3390/agronomy9100597

Wellburn RW (1994). The spectral determination of chlorophylls a and b, as well as total carotenoids, using various solvents with spectrophotometers of different resolution. Journal of Plant Physiology 144:307-313. https://doi.org/10.1016/S0176-1617(11)81192-2

Yadava P, Kaushal J, Gautam A, Parmar H, Singh I (2016). Physiological and biochemical effects of 24-epibrassinolide on heat-stress adaptation in maize (Zea mays L.). Natural Science 8(4):171-179. http://dx.doi.org/10.4236/ns.2016.84020

Yakhin OI, Lubyanov AA, Yakhin IA, Brown PH (2017). Biostimulants in plant science: a global perspective. Frontiers in Plant Science 7:2049. https://doi.org/10.3389/fpls.2016.02049

Yao Y, Wang X, Chen B, Zhang M, Ma J (2020). Seaweed extract improved yields, leaf photosynthesis, ripening time, and net returns of tomato (Solanum lycopersicum Mill.). ACS Omega 5(8):4242-4249. https://doi.org/10.1021/acsomega.9b04155

Yin C, Berninger F, Li C (2006). Photosynthetic responses of Populus przewalski subjected to drought stress. Photosynthetica 44:62-68. https://doi.org/10.1007/s11099-005-0159-y 
Zafar SA, Hameed A, Nawaz MA, Wei M, Noor MA, Hussain M, Rehman M (2018). Mechanisms and molecular approaches for heat tolerance in rice (Oryza sativa L.) under climate change scenario. Journal of Integrative Agriculture 17(4):726738. https://doi.org/10.1016/S2095-3119(17)61718-0

Zhang X, Ervin EH (2008). Impact of seaweed extract-based cytokinins and zeatin riboside on creeping bentgrass heat tolerance. Crop Science 48:364-370. https://doi.org/10.2135/cropsci2007.05.0262

Zhang X, Wang K, Ervin EH (2010). Optimizing dosages of seaweed extract-based cytokinins and zeatin riboside for improving creeping bentgrass heat tolerance. Crop Science 50:316-320. https://doi.org/10.2135/cropsci2009.02.0090

Zhou J, Wang J, Li X, Xia XJ, Zhou YH, Shi K, ... Yu JQ (2014). $\mathrm{H}_{2} \mathrm{O}_{2}$ mediates the crosstalk of brassinosteroid and abscisic acid in tomato responses to heat and oxidative stresses. Journal of Experimental Botany 65:4371-4383. https://doi.org/10.1093/jxb/eru217

OPEN ACCESS

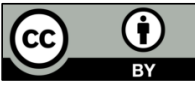

The journal offers free, immediate, and unrestricted access to peer-reviewed research and scholarly work. Users are allowed to read, download, copy, distribute, print, search, or link to the full texts of the articles, or use them for any other lawful purpose, without asking prior permission from the publisher or the author.

License - Articles published in Notulae Botanicae Horti Agrobotanici Cluj-Napoca are Open-Access, distributed under the terms and conditions of the Creative Commons Attribution (CC BY 4.0) License. (c) Articles by the authors; UASVM, Cluj-Napoca, Romania. The journal allows the author(s) to hold the copyright/to retain publishing rights without restriction. 